NIST Technical Note 2102

\title{
Heat Release Rates of Multiple Transient Combustibles
}

Kevin McGrattan

This publication is available free of charge from: https://doi.org/10.6028/NIST.TN.2102
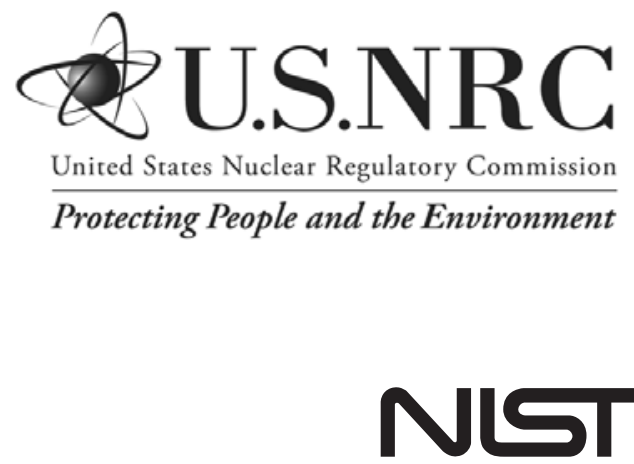

National Institute of Standards and Technology

U.S. Department of Commerce 

NIST Technical Note 2102

\section{Heat Release Rates of Multiple Transient Combustibles}

Kevin McGrattan

Fire Research Division

Engineering Laboratory

This publication is available free of charge from:

https://doi.org/10.6028/NIST.TN.2102

July 2020
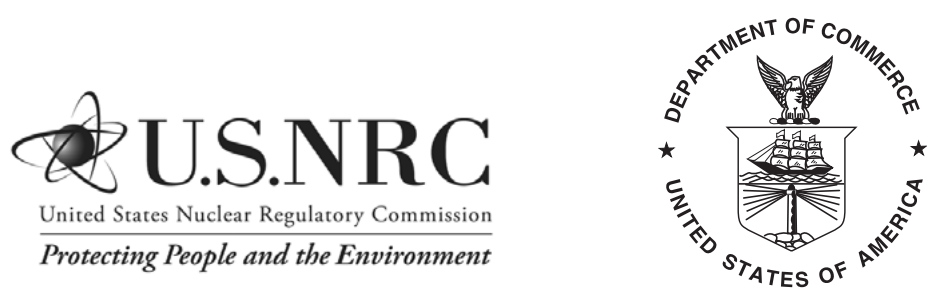

U.S. Department of Commerce Wilbur L. Ross, Jr., Secretary 
Certain commercial entities, equipment, or materials may be identified in this document in order to describe an experimental procedure or concept adequately. Such identification is not intended to imply recommendation or endorsement by the National Institute of Standards and Technology, nor is it intended to imply that the entities, materials, or equipment are necessarily the best available for the purpose.

National Institute of Standards and Technology Technical Note 2102

Natl. Inst. Stand. Technol. Tech. Note 2102, 65 pages (July 2020) CODEN: NTNOEF

This publication is available free of charge from: https://doi.org/10.6028/NIST.TN.2102 


\begin{abstract}
This report documents heat release rate measurements of various transient combustibles; that is, non-permanent items found in industrial settings that can potentially contribute to an accidental fire. These items are often included in hypothetical fire scenarios that are modeled as part of risk analyses. Of particular interest in these experiments is the functional relationship between the peak heat release rate and the number of replicate items.
\end{abstract}

\title{
Key words
}

Oxygen consumption calorimetry, Transient combustibles. 


\section{Contents}

1 Introduction 1

2 Description of Experiments 2

3 Results 5

3.1 Test 1, Single Box with Crinkle Paper . . . . . . . . . . . . . . . . 7

3.2 Test 2, Two Boxes with Crinkle Paper . . . . . . . . . . . . . . . 8

3.3 Test 3, Four Boxes with Crinkle Paper . . . . . . . . . . . . . . . . 9

3.4 Test 4, Eight Boxes with Crinkle Paper . . . . . . . . . . . . . . . . . 10

3.5 Test 5, Two Pallets, Stacked . . . . . . . . . . . . . . . . 11

3.6 Test 6, Four Pallets, Stacked _ . . . . . . . . . . . . . . . . . 12

3.7 Test 7, Four Pallets, Two Stacks of Two . . . . . . . . . . . . . . . 13

3.8 Test 8, Eight Pallets, Four Stacks of Two . . . . . . . . . . . . . . 14

3.9 Test 9, Eight Pallets, One Stack . . . . . . . . . . . . . . . 15

3.10 Test 10, Single Box of Rags . . . . . . . . . . . . . . . 16

3.11 Test 11, Four Boxes of Rags . . . . . . . . . . . . . . . . . . 17

3.12 Test 12, Four Boxes of Rags, Separated . . . . . . . . . . . . . 18

3.13 Test 13, Single Wood Crib . . . . . . . . . . . . . . . . . . . 19

3.14 Test 14, Two Wood Cribs, Side by Side . . . . . . . . . . . . . . 20

3.15 Test 15, Four Wood Cribs, Two by Two Array . . . . . . . . . . . . . . . 21

3.16 Test 16, Eight Wood Cribs, Four Stacks of Two . . . . . . . . . . . . . 22

3.17 Test 17, Single Plastic Trash Bin Filled with Crinkle Paper . . . . . . . . . 23

3.18 Test 18, Two Plastic Trash Bins Filled with Crinkle Paper . . . . . . . . . . 24

3.19 Test 19, Four Plastic Trash Bins Filled with Crinkle Paper . . . . . . . . . . 25

3.20 Test 20, Four Plastic Trash Bins Filled with Crinkle Paper Atop Two Pallets 26

3.21 Test 21, Eight Boxes Filled with Crinkle Paper Atop Two Pallets . . . . . . 27

3.22 Test 22, Single Hanging Plastic Tarp . . . . . . . . . . . . . . . . . . 28

3.23 Test 23, Single Hanging Plastic Tarp, Replicate 2 . . . . . . . . . . . . . . 29

3.24 Test 24, Two Hanging, Overlapping Plastic Tarps . . . . . . . . . . . . . 30

3.25 Test 25, Single Box, Plastic Commodity . . . . . . . . . . . . . . . 31

3.26 Test 26, Two Boxes, Plastic Commodity . . . . . . . . . . . . . . 32

3.27 Test 27, Four Boxes, Plastic Commodity . . . . . . . . . . . . . . . 33

3.28 Test 28, Eight Boxes, Plastic Commodity . . . . . . . . . . . . . . . . 34

3.29 Test 29, Single Plastic Bin Filled with Rags and Paper . . . . . . . . . . . . 35

3.30 Test 30, Two Plastic Bins Filled with Rags and Paper . . . . . . . . . . . . 36

3.31 Test 31, Four Plastic Bins Filled with Rags and Paper . . . . . . . . . . . . 37

3.32 Test 32, Single Box with Crinkle Paper, Single Ignition Point . . . . . . . . 38

3.33 Test 33, Two Boxes with Crinkle Paper, Single Ignition Point . . . . . . . . 39

3.34 Test 34, Four Boxes with Crinkle Paper, Single Ignition Point . . . . . . . . 40

3.35 Test 35, Eight Boxes of Rags . . . . . . . . . . . . . . . . . . 41 
3.36 Test 36, Two Plastic Trash Bins Filled with Crinkle Paper, One Inside the Other ............................ 42

3.37 Test 37, Four Boxes with Crinkle Paper, Separated . . . . . . . . . . . . 43

3.38 Test 38, Four Boxes with Crinkle Paper, Separated . . . . . . . . . . . . . 44

3.39 Test 39, Four Plastic Trash Bins Filled with Crinkle Paper, Separated . . . . 45

3.40 Test 40, Four Boxes, Plastic Commodity . . . . . . . . . . . . . . . . 46

4 Discussion $\quad 47$

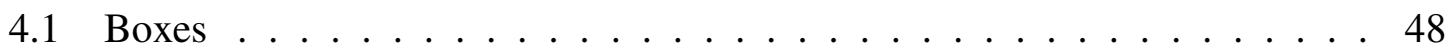

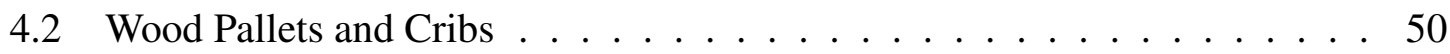

4.3 Plastic Trash Bins . . . . . . . . . . . . . . . . . . . 52

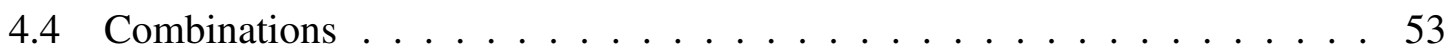

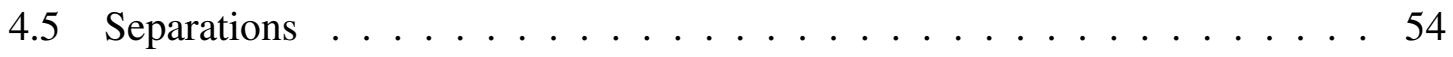

5 Conclusion $\quad 55$

$\begin{array}{ll}\text { Acknowledgments } & 55\end{array}$

$\begin{array}{ll}\text { References } & 55\end{array}$

\section{List of Tables}

1 Average heat and product yields of the various test items $\ldots \ldots \ldots$

2 Summary of test results .................. 6

\section{List of Figures}

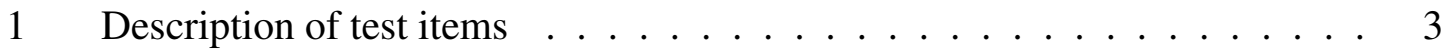

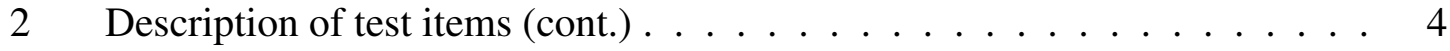

3 Photographs of Test $1 \ldots \ldots \ldots \ldots$

4 Photographs of Test $2 \ldots \ldots \ldots \ldots$

5 Photographs of Test $3 \ldots \ldots \ldots \ldots$

6 Photographs of Test $4 \ldots \ldots \ldots \ldots$

7 Photographs of Test $5 \ldots \ldots \ldots \ldots \ldots \ldots$

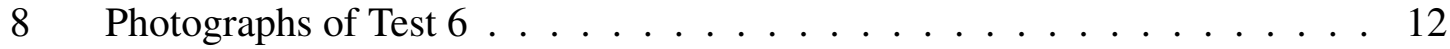

9 Photographs of Test $7 \ldots \ldots \ldots \ldots$

10 Photographs of Test $8 \ldots \ldots \ldots \ldots \ldots$

11 Photographs of Test $9 \ldots \ldots \ldots \ldots \ldots$

12 Photographs of Test $10 \ldots \ldots \ldots \ldots$

13 Photographs of Test $11 \ldots \ldots \ldots \ldots \ldots$

14 Photographs of Test $12 \ldots \ldots \ldots \ldots \ldots$

15 Photographs of Test $13 \ldots \ldots \ldots \ldots$

16 Photographs of Test $14 \ldots \ldots \ldots \ldots$ 
17 Photographs of Test $15 \ldots \ldots \ldots \ldots \ldots \ldots \ldots$

18 Photographs of Test $16 \ldots \ldots \ldots \ldots \ldots 22$

19 Photographs of Test $17 \ldots \ldots \ldots \ldots$

20 Photographs of Test $18 \ldots \ldots \ldots \ldots \ldots$

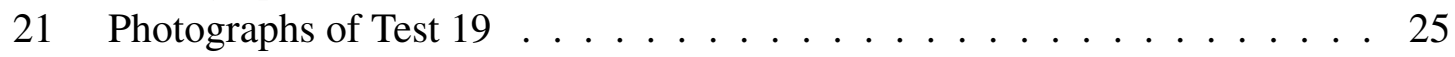

22 Photographs of Test $20 \ldots \ldots \ldots \ldots \ldots$

23 Photographs of Test $21 \ldots \ldots \ldots \ldots \ldots$

24 Photographs of Test $22 \ldots \ldots \ldots \ldots \ldots \ldots$

25 Photographs of Test $23 \ldots \ldots \ldots \ldots$

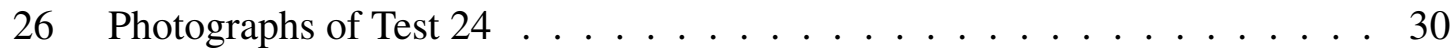

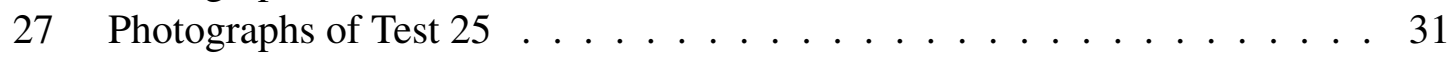

28 Photographs of Test $26 \ldots \ldots \ldots \ldots \ldots$

29 Photographs of Test $27 \ldots \ldots \ldots$. . . . . . . . . . . . . . . . . . . . . . . . . . . . . . . .

30 Photographs of Test $28 \ldots \ldots \ldots \ldots \ldots \ldots$

31 Photographs of Test $29 \ldots \ldots \ldots \ldots \ldots$

32 Photographs of Test $30 \ldots \ldots \ldots \ldots \ldots \ldots$

33 Photographs of Test $31 \ldots \ldots \ldots \ldots \ldots \ldots$

34 Photographs of Test $32 \ldots \ldots \ldots \ldots \ldots$

35 Photographs of Test $33 \ldots \ldots \ldots \ldots$

36 Photographs of Test $34 \ldots \ldots \ldots \ldots$. . . . . . . . . . . . . . . . . . . . . . . . . .

37 Photographs of Test $35 \ldots \ldots \ldots \ldots \ldots \ldots$

38 Photographs of Test $36 \ldots \ldots \ldots \ldots$. . . . . . . . . . . . . . 42

39 Photographs of Test $37 \ldots \ldots \ldots \ldots \ldots$

40 Photographs of Test $38 \ldots \ldots \ldots \ldots \ldots$. . . . . . . . . . . . . . . . . . . . . . . . . . . . . . 44

41 Photographs of Test $39 \ldots \ldots \ldots \ldots$. . . . . . . . . . . . 45

42 Photographs of Test $40 \ldots \ldots \ldots$. . . . . . . . . . . . . 46

43 Increase in peak HRR as a function of increasing surface area . . . . . . . . 47

44 HRR of boxes filled with paper and ignited at a single point . . . . . . . . . 48

45 Heat Release Rate of boxes filled with paper, plastic and rags . . . . . . . . 49

46 Heat Release Rate of pallets and cribs . . . . . . . . . . . . . . . . . . . 51

47 Heat Release Rate of plastic trash bins . . . . . . . . . . . . . . . . . . 52

48 Heat Release Rate of four boxes filled with crinkle paper . . . . . . . . . . 54 


\section{Introduction}

In 2018, the Nuclear Regulatory Commission (NRC) and the Electric Power Research Institute (EPRI) collaborated on a set of experiments to measure the heat release rate (HRR) of "transient combustibles;" that is, items one might find in industrial spaces on a temporary basis, in particular nuclear power plants. For example, during maintenance work, items such as trash bins, pallets, cardboard boxes, and so on, might remain in an area for a limited time period. These items are typically not accounted for when designing the fire protection system, but they are considered as part of a probabilistic risk analysis (PRA). A key parameter in such an analysis is the maximum heat release rate an item can generate if it accidentally catches fire, and the time to reach that peak following ignition.

The results of 290 HRR measurements made by the NRC and EPRI are documented in Ref. [1]. Additional analysis is found in Ref. [2]. The purpose of the current report is to document additional experiments to determine the relationship between the peak HRR and the number of multiple combustible items. In other words, if the peak HRR of a single item is $100 \mathrm{~kW}$, will the peak HRR of two such items be $200 \mathrm{~kW}$ ? Or, if the peak HRR of item A is $100 \mathrm{~kW}$, and item B $200 \mathrm{~kW}$, will the peak HRR of items A and B be $300 \mathrm{~kW}$ ? 


\section{Description of Experiments}

In December 2019 and February 2020 ${ }^{1}, 40$ fire experiments were conducted at the National Fire Research Laboratory at NIST, Gaithersburg, on behalf of the U.S. Nuclear Regulatory Commission. All of the experiments but two were conducted under a $6.1 \mathrm{~m}(20 \mathrm{ft})$ by $6.1 \mathrm{~m}$ hood with a nominal capacity of $3 \mathrm{MW}$. Two experiments were conducted under a larger

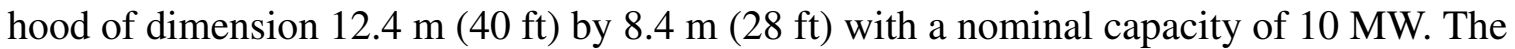
exhaust rate of the smaller hood ranged between approximately $13 \mathrm{~m}^{3} / \mathrm{s}\left(27500 \mathrm{ft}^{3} / \mathrm{min}\right)$ to $17 \mathrm{~m}^{3} / \mathrm{s}\left(36000 \mathrm{ft}^{3} / \mathrm{min}\right)$. The larger hood was set to approximately $42 \mathrm{~m}^{3} / \mathrm{s}\left(89000 \mathrm{ft}^{3} / \mathrm{min}\right)$. Details on the facility and measurements can be found in Ref. [3].

The items burned are described in Figs. 1 and 2. These consist of commercially available materials constructed mainly of wood, paper, and plastics. Each item was weighed ${ }^{2}$ before and after the experiment on a load cell accurate to $10 \mathrm{~g}$. A steel garbage can partially filled with water was used to collect and weigh the burn residue after each experiment.

The fires were all ignited using one or more $7.5 \mathrm{~cm}$ ( 3 in) segments of approximately $1 \mathrm{~cm}(0.5 \mathrm{in})$ diameter cotton rope soaked in approximately $10 \mathrm{~mL}$ of acetone. For some items like the wood cribs and pallets, a small amount of crinkle paper was used to sustain the ignition until steady burning was achieved.

The floor beneath the burning item was protected with a single layer of gypsum board covered by a single layer of concrete board. If plastics were involved, the test item was placed in a steel pan to contain the molten plastic.

\footnotetext{
${ }^{1} 36$ of 40 experiments were conducted in December 2019; 4 experiments were conducted in February 2020.

${ }^{2}$ The mass measurements were made with a Mettler Toledo Jaguar series load cell with a range from $10 \mathrm{~g}$ to $150 \mathrm{~kg}$.
} 
Box \#1: Single-wall corrugated box with nominal dimensions $61 \mathrm{~cm}$ by $61 \mathrm{~cm}$ by $46 \mathrm{~cm}$ ( 24 in by 24 in by 18 in) filled with "crinkle paper," a common packing material made by shredding craft paper. The box alone had a mass of approximately $1.6 \mathrm{~kg}$ $(3.5 \mathrm{lb})$, and the box and paper combined had a mass of $8.0 \mathrm{~kg}$ (18 lb). The box top flaps were closed, end over end, but not sealed with tape.

Box \#2: Single-wall corrugated box with nominal dimensions $41 \mathrm{~cm}$ by $30 \mathrm{~cm}$ by $30 \mathrm{~cm}$ (16 in by 12 in by 12 in) filled with dry cotton rags. The box alone had a mass of approximately $0.8 \mathrm{~kg}(1.8 \mathrm{lb})$, and the box and rags combined had a mass of approximately $4.5 \mathrm{~kg}(10 \mathrm{lb})$. The box top was taped shut for the burns.

Box \#3: Single-wall corrugated box with nominal dimensions $53 \mathrm{~cm}$ by $53 \mathrm{~cm}$ by $53 \mathrm{~cm}$ (21 in by 21 in by 21 in) filled with 100 rigid polystyrene cups. The corrugated box and inner liners alone had a mass of approximately $3.5 \mathrm{~kg}(7.7 \mathrm{lb})$, and the total combined mass was approximately $7.0 \mathrm{~kg}(15 \mathrm{lb})$. The top was taped shut. This item was originally developed by FM Global for use in rack storage commodity testing.

Tarp: Lightweight plastic tarp with dimensions $3.0 \mathrm{~m}$ by $2.4 \mathrm{~m}$ (10 ft by $8 \mathrm{ft})$ draped across a steel rod. Its mass was approximately $0.8 \mathrm{~kg}(1.8 \mathrm{lb})$.
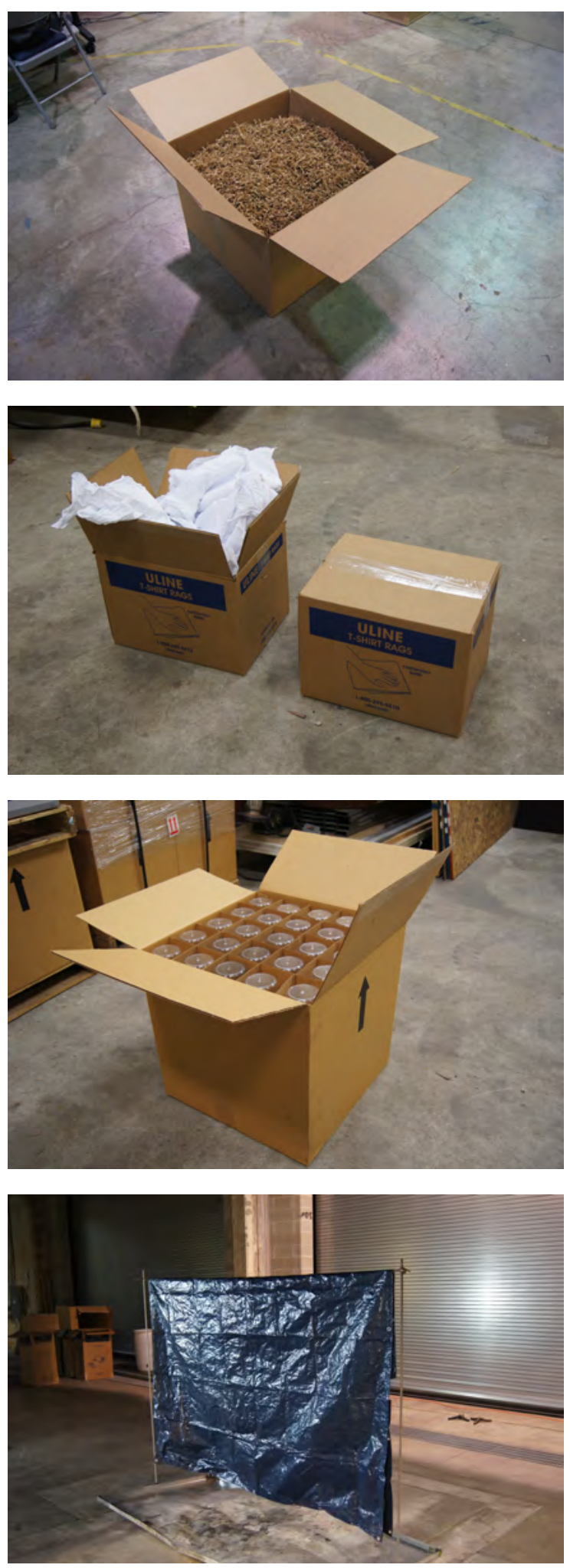

Figure 1: Description of test items. 
Pallet: Pine wood pallet with dimensions $122 \mathrm{~cm}$ by $102 \mathrm{~cm}$ by $12 \mathrm{~cm}$ (48 in by 40 in by 4.75 in). Its mass was approximately $16.0 \mathrm{~kg}(35 \mathrm{lb})$. Its moisture content was less than $5 \%$. Shown at right are two pallets, which were ignited with $1 \mathrm{~kg}(2.2 \mathrm{lb})$ of crinkle paper distributed evenly throughout the lower pallet.

Crib: Pine wood crib with dimensions $56 \mathrm{~cm}$ by $56 \mathrm{~cm}$ by $46 \mathrm{~cm}$ (22 in by 22 in by 18 in) constructed of slats with a cross-section $3.8 \mathrm{~cm}$ (1.5 in) square. Its mass was approximately $39 \mathrm{~kg}(86 \mathrm{lb})$. Its moisture content was less than $5 \%$. It was ignited with $0.75 \mathrm{~kg}(1.7 \mathrm{lb})$ of crinkle paper stuffed in the space below the first row of slats.

Bin \#1: Cylindrical, open-top plastic trash bin approximately $71 \mathrm{~cm}$ (28 in) tall with an opening diameter of $51 \mathrm{~cm}$ (20 in). Its mass was approximately $2.7 \mathrm{~kg}(5.9 \mathrm{lb})$. The bin was half filled with crinkle paper for a combined mass of $5.0 \mathrm{~kg}(11 \mathrm{lb})$.

Bin \#2: The same as Bin \#1, but with the rags and cardboard of Box \#2 mixed in. The total mass was approximately $9.5 \mathrm{~kg}(21 \mathrm{lb})$.
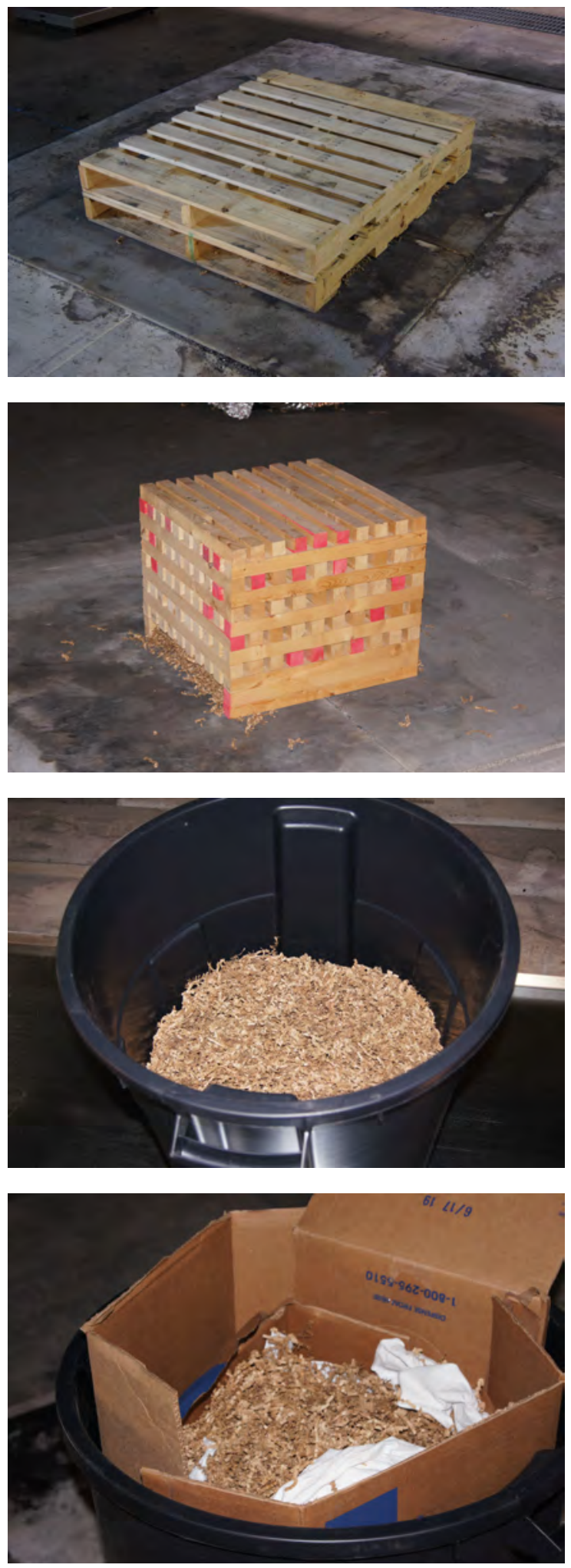

Figure 2: Description of test items (cont.) 


\section{Results}

The heat release rate (HRR) and photographs of each experiment are given in Figs. 3 through 42.

A summary of the 40 experiments is given in Table 2. The uncertainty of each measurement includes both aleatoric and epistemic sources and is expressed in terms of a $95 \%$ confidence interval, sometimes referred to as $2 \sigma$ uncertainty because it is equivalent to two standard deviations. The uncertainty calculation for a particular heat release rate measurement is fairly complex, but, in general, the relative uncertainty is approximately $7 \%$ for general combustibles for which the combustion kinetics are unknown; and $4.5 \%$ for materials with known chemical make-up. The difference in uncertainty values is largely due to the uncertainty of the heat of combustion based on oxygen consumption, $\Delta H_{\mathrm{O}_{2}}$. For these experiments, items containing only wood and paper were taken as "cellulose" and assigned a value of $13.61 \mathrm{~kJ} / \mathrm{kg}$ of oxygen consumed [4]; whereas an average value of $13.1 \mathrm{~kJ} / \mathrm{kg}$ was assigned to the items that contained plastics or other materials. Further details of the calorimetry and uncertainty calculation can be found in Ref. [3].

Note that in Table 2 where no value is given, the measured quantity was found to be less than its uncertainty value.

Table 1 provides the average heats of combustion and product yields for the items described in Figs. 1 and 2, excluding the tarps for which reliable yields could not be determined. The gas species and soot yields and the heat of combustion are calculated by dividing the measured total heat or mass in the exhaust hood by the measured mass loss of the fuels. That is, these values represent heat or mass generated per unit mass of fuel consumed. The Residue Yield is calculated by dividing the final mass by the initial mass of the item. Note that in order to burn as much of the items as possible, it was necessary to mix up the residue with a pike hook until all of the combustible material had been consumed.

Table 1: Average heat and product yields of the various test items.

\begin{tabular}{|c|c|c|c|c|c|}
\hline Item & $\Delta H(\mathrm{MJ} / \mathrm{kg})$ & CO Yield & $\mathrm{CO}_{2}$ Yield & Soot Yield & Residue Yield \\
\hline \hline Box \#1 & $14.8 \pm 0.5$ & $0.039 \pm 0.001$ & $1.48 \pm 0.05$ & $0.0014 \pm 0.0003$ & $0.031 \pm 0.016$ \\
\hline Box \#2 & $13.8 \pm 0.5$ & $0.066 \pm 0.003$ & $1.33 \pm 0.05$ & $0.0042 \pm 0.0019$ & $0.035 \pm 0.020$ \\
\hline Box \#3 & $25.4 \pm 1.5$ & $0.055 \pm 0.002$ & $2.13 \pm 0.08$ & $0.0976 \pm 0.014$ & $0.003 \pm 0.002$ \\
\hline Pallet & $17.2 \pm 0.5$ & $0.031 \pm 0.001$ & $1.66 \pm 0.06$ & $0.0033 \pm 0.0006$ & $0.059 \pm 0.024$ \\
\hline Crib & $16.7 \pm 0.5$ & $0.023 \pm 0.001$ & $1.63 \pm 0.06$ & $0.0020 \pm 0.0003$ & $0.053 \pm 0.034$ \\
\hline Bin \#1 & $27.6 \pm 1.7$ & $0.021 \pm 0.004$ & $2.18 \pm 0.08$ & $0.0153 \pm 0.0027$ & $0.090 \pm 0.040$ \\
\hline Bin \#2 & $20.8 \pm 1.2$ & $0.031 \pm 0.001$ & $1.80 \pm 0.07$ & $0.0099 \pm 0.0029$ & $0.040 \pm 0.020$ \\
\hline
\end{tabular}




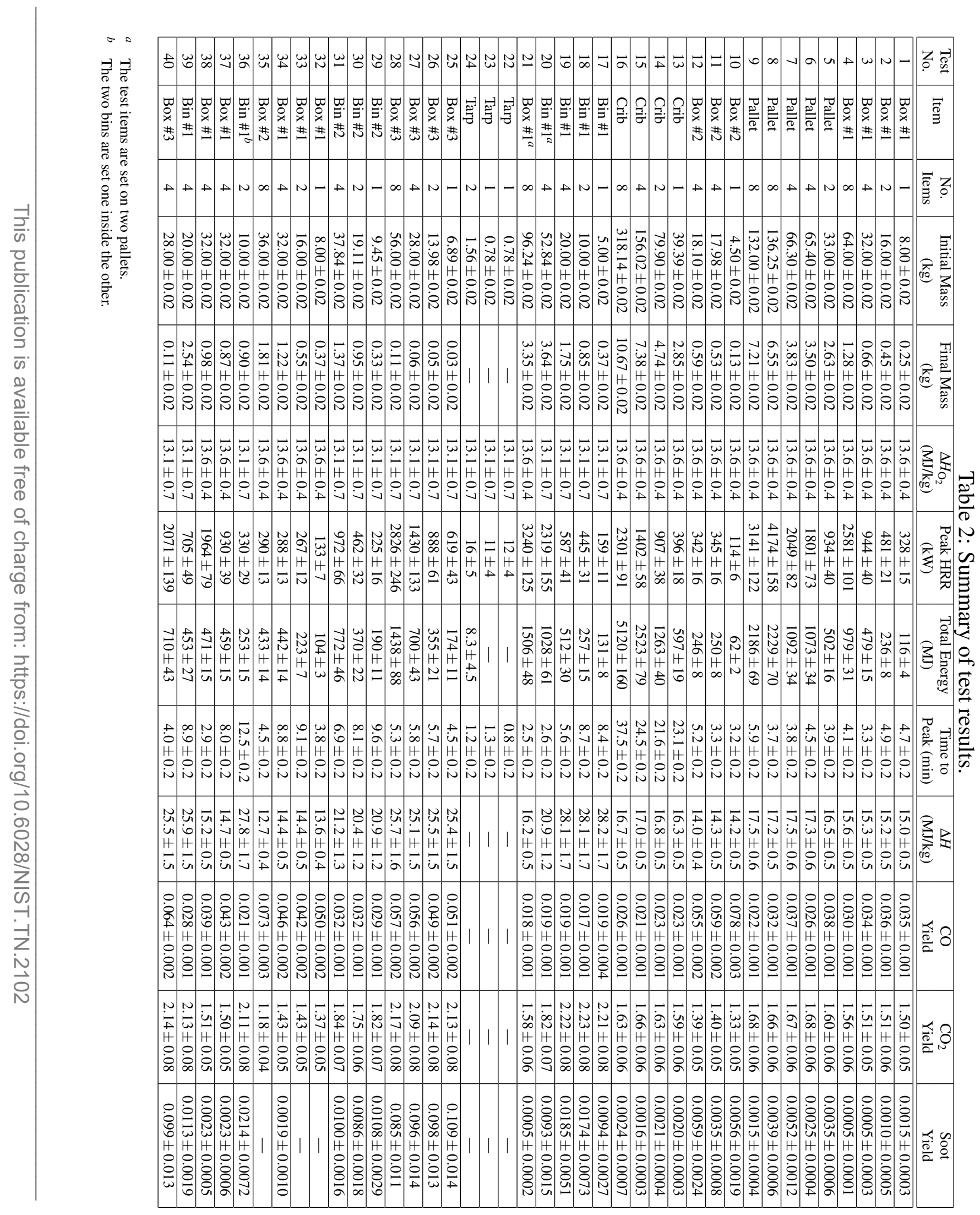




\subsection{Test 1, Single Box with Crinkle Paper}

Single box with crinkle paper, ignited at the base of each vertical face. The spike in HRR just after 15 min resulted from stirring the residual material.
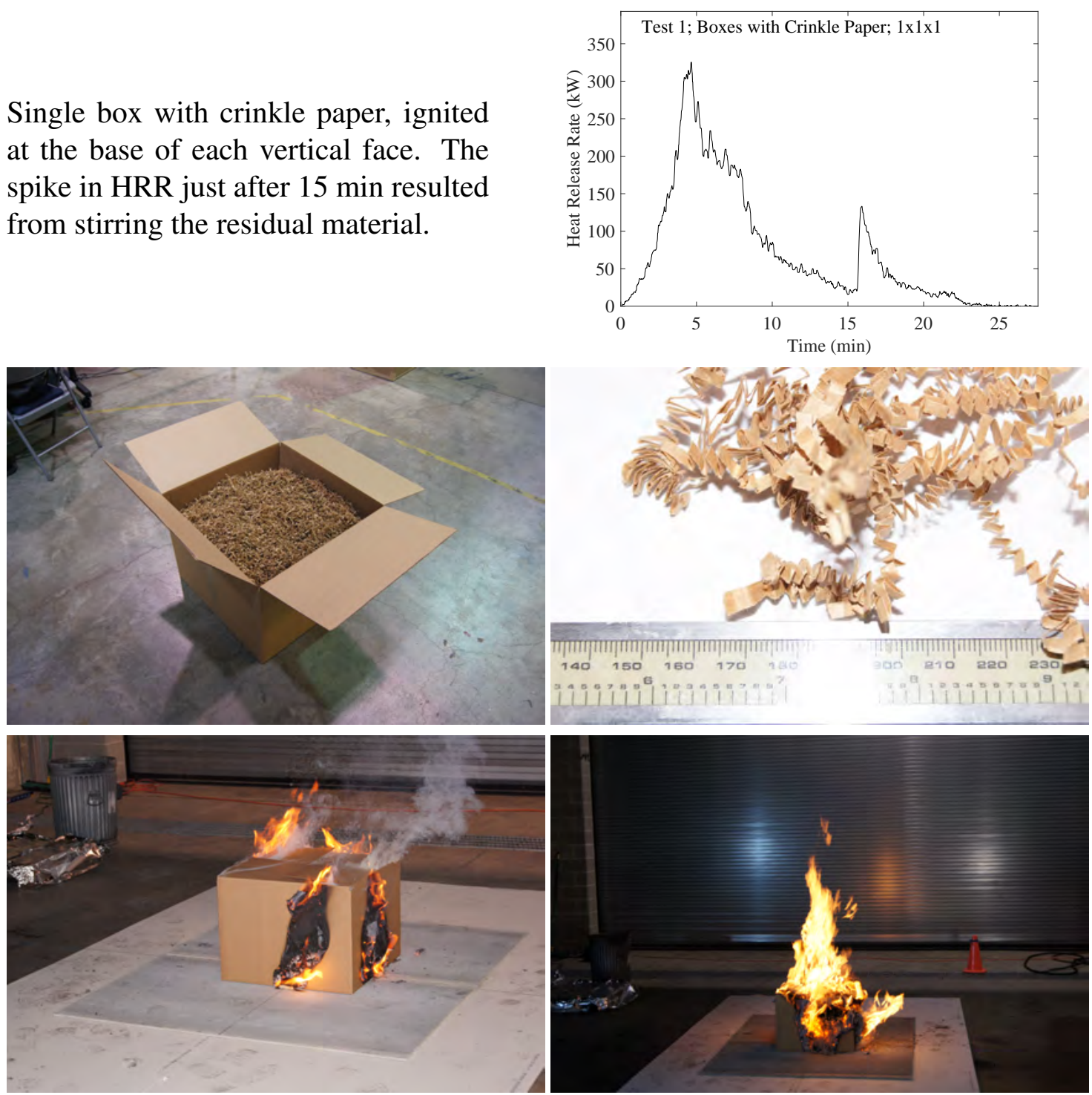

Figure 3: Heat release rate and photographs of Test 1. 


\subsection{Test 2, Two Boxes with Crinkle Paper}

Two boxes with crinkle paper, ignited at the base of each vertical face. The spike in HRR just after 25 min resulted from stirring the residual material.
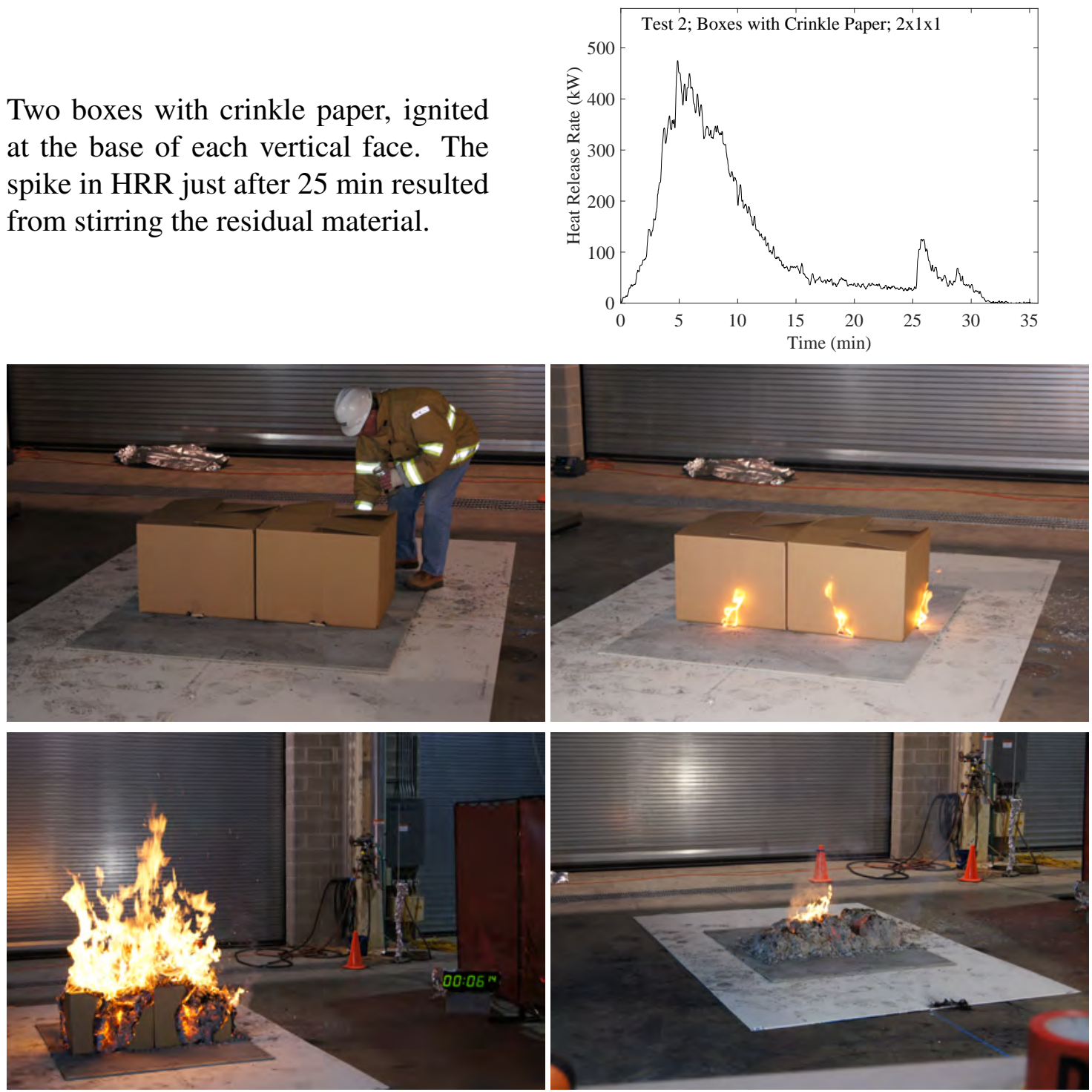

Figure 4: Heat release rate and photographs of Test 2. 


\subsection{Test 3, Four Boxes with Crinkle Paper}

Four boxes with crinkle paper, ignited at the base of each vertical face. The spike in HRR after $30 \mathrm{~min}$ resulted from stirring the residual material.
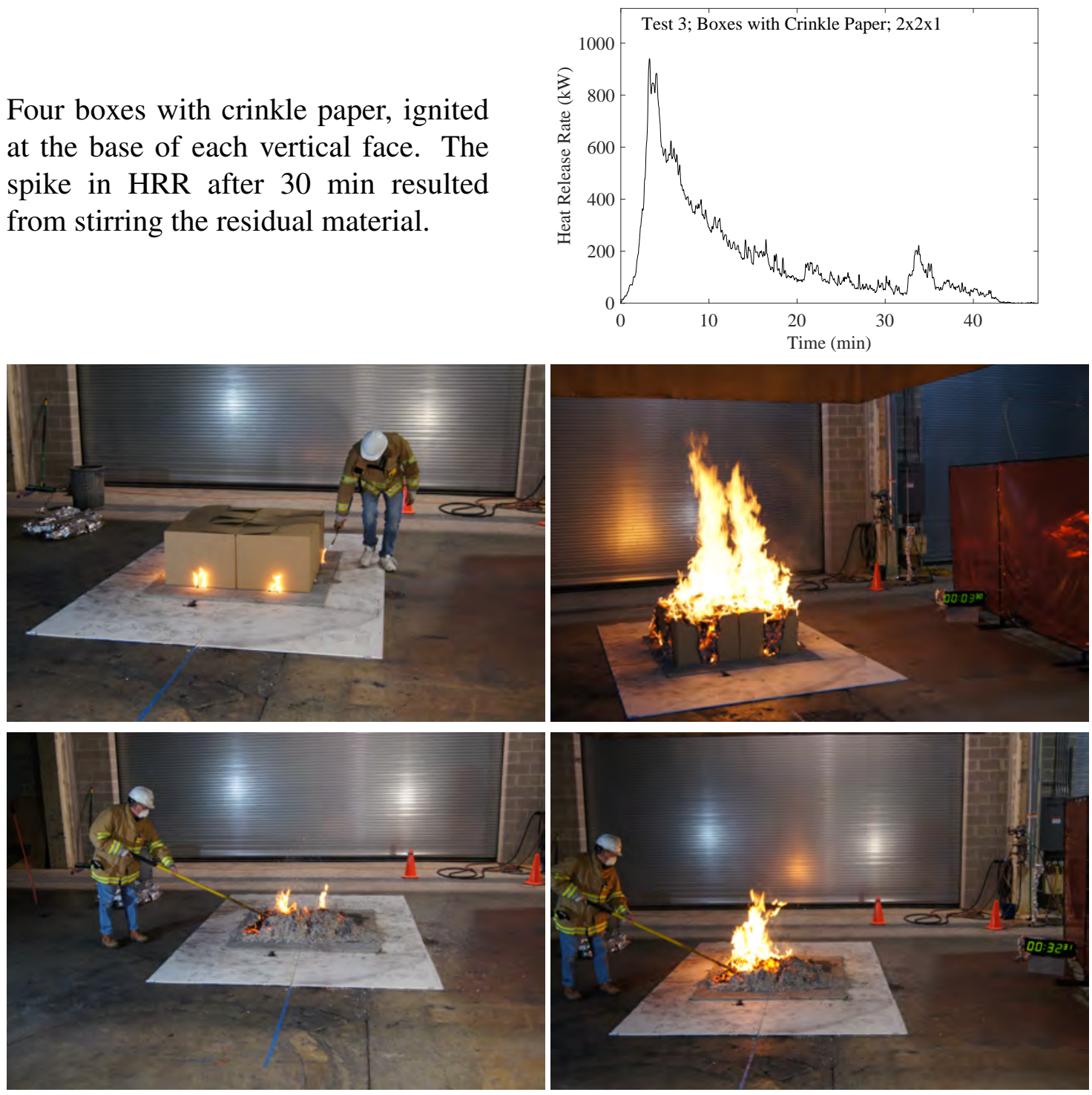

Figure 5: Heat release rate and photographs of Test 3. 


\subsection{Test 4, Eight Boxes with Crinkle Paper}

Eight boxes with crinkle paper, ignited at the base of each vertical face. The spikes in HRR after 30 min resulted from stirring the residual material.
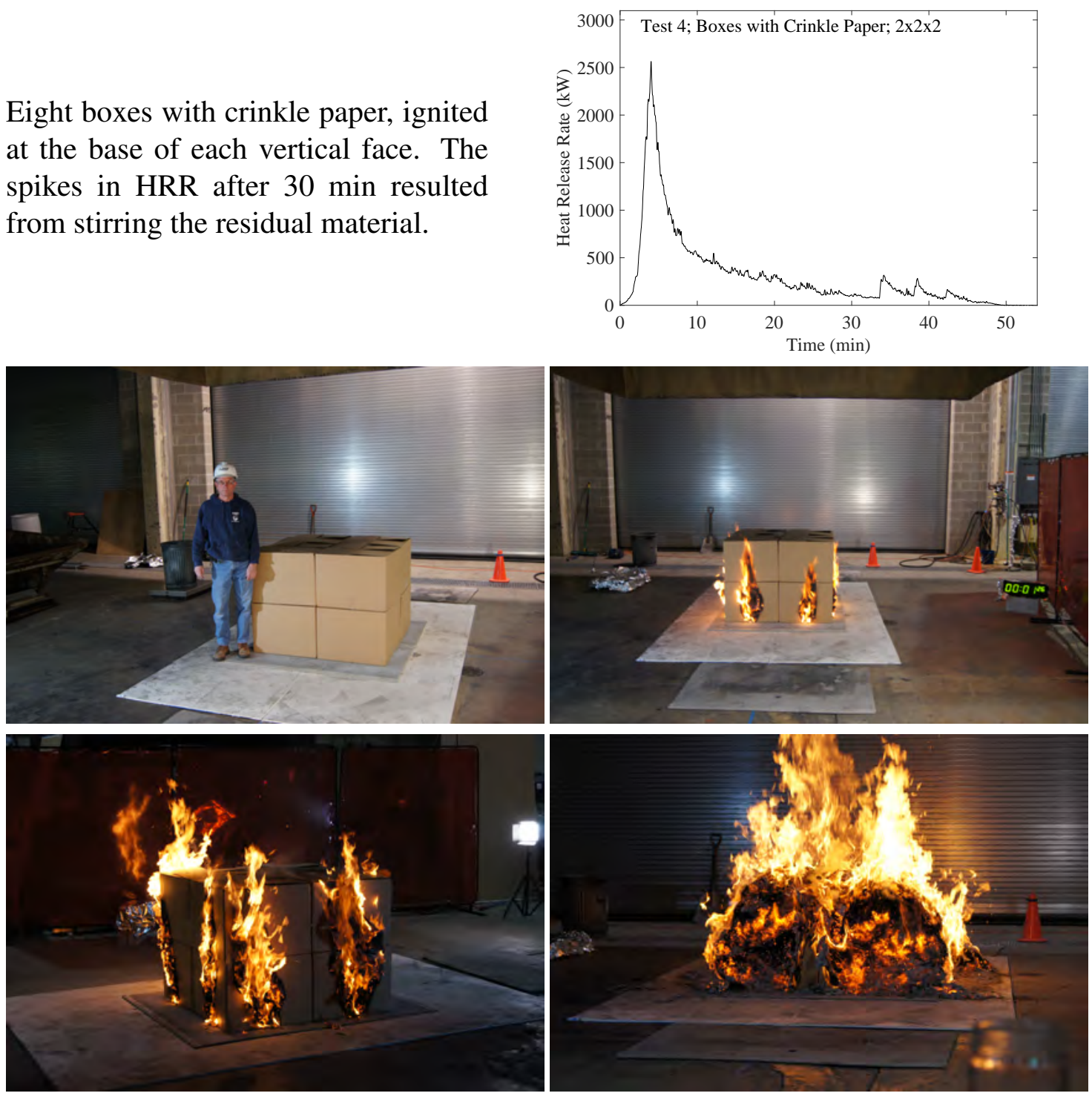

Figure 6: Heat release rate and photographs of Test 4. 


\subsection{Test 5, Two Pallets, Stacked}

Two wood pallets with $1 \mathrm{~kg}$ crinkle paper distributed evenly along the bottom of the stack. The fire was ignited with four igniters, one in each quadrant of the bottom pallet.
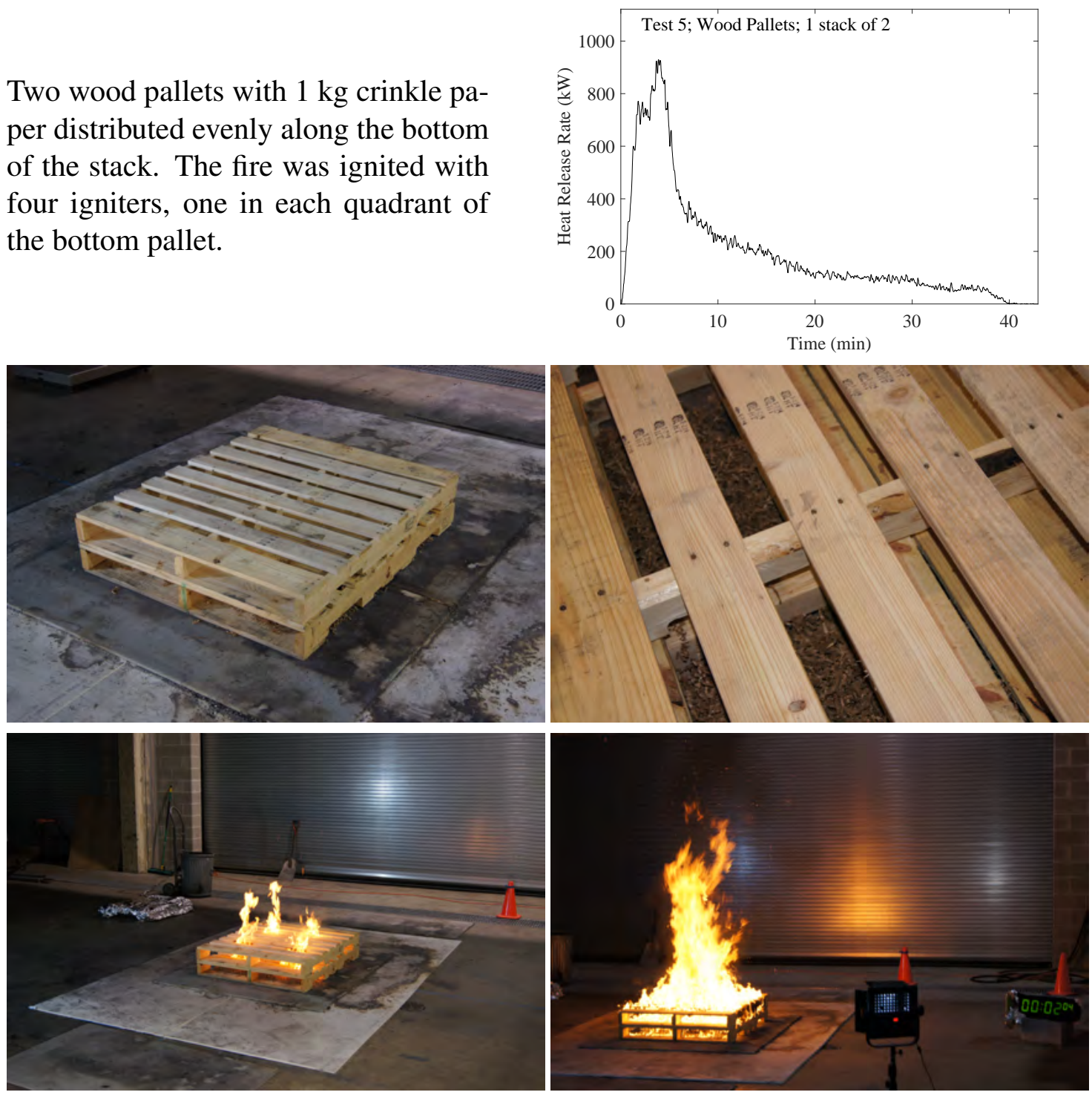

Figure 7: Heat release rate and photographs of Test 5. 


\subsection{Test 6, Four Pallets, Stacked}

Four wood pallets, stacked, with $1 \mathrm{~kg}$
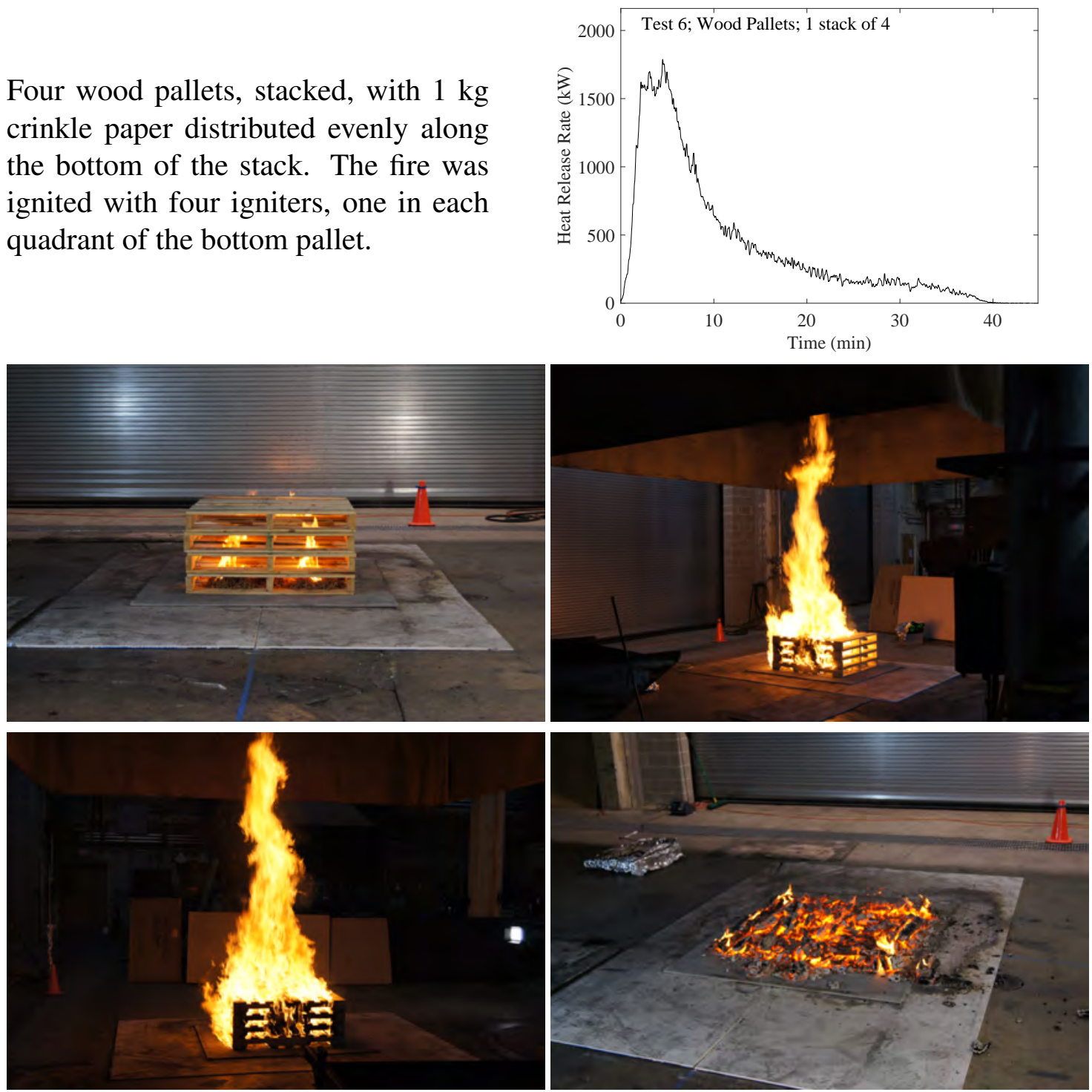

Figure 8: Heat release rate and photographs of Test 6. 


\subsection{Test 7, Four Pallets, Two Stacks of Two}

Four wood pallets, two stacks of two,
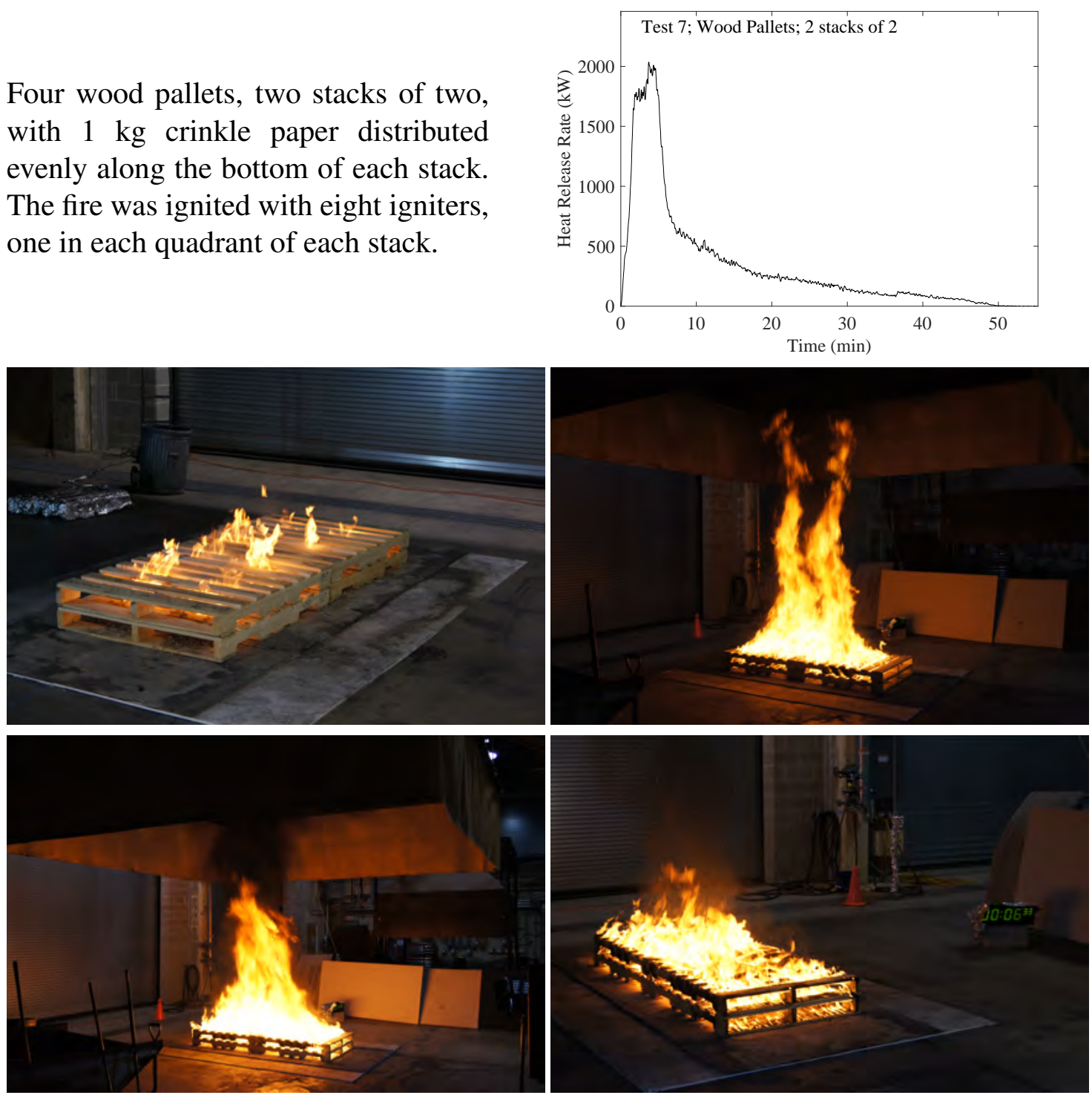

Figure 9: Heat release rate and photographs of Test 7. 


\subsection{Test 8, Eight Pallets, Four Stacks of Two}

Eight wood pallets, four stacks of two,
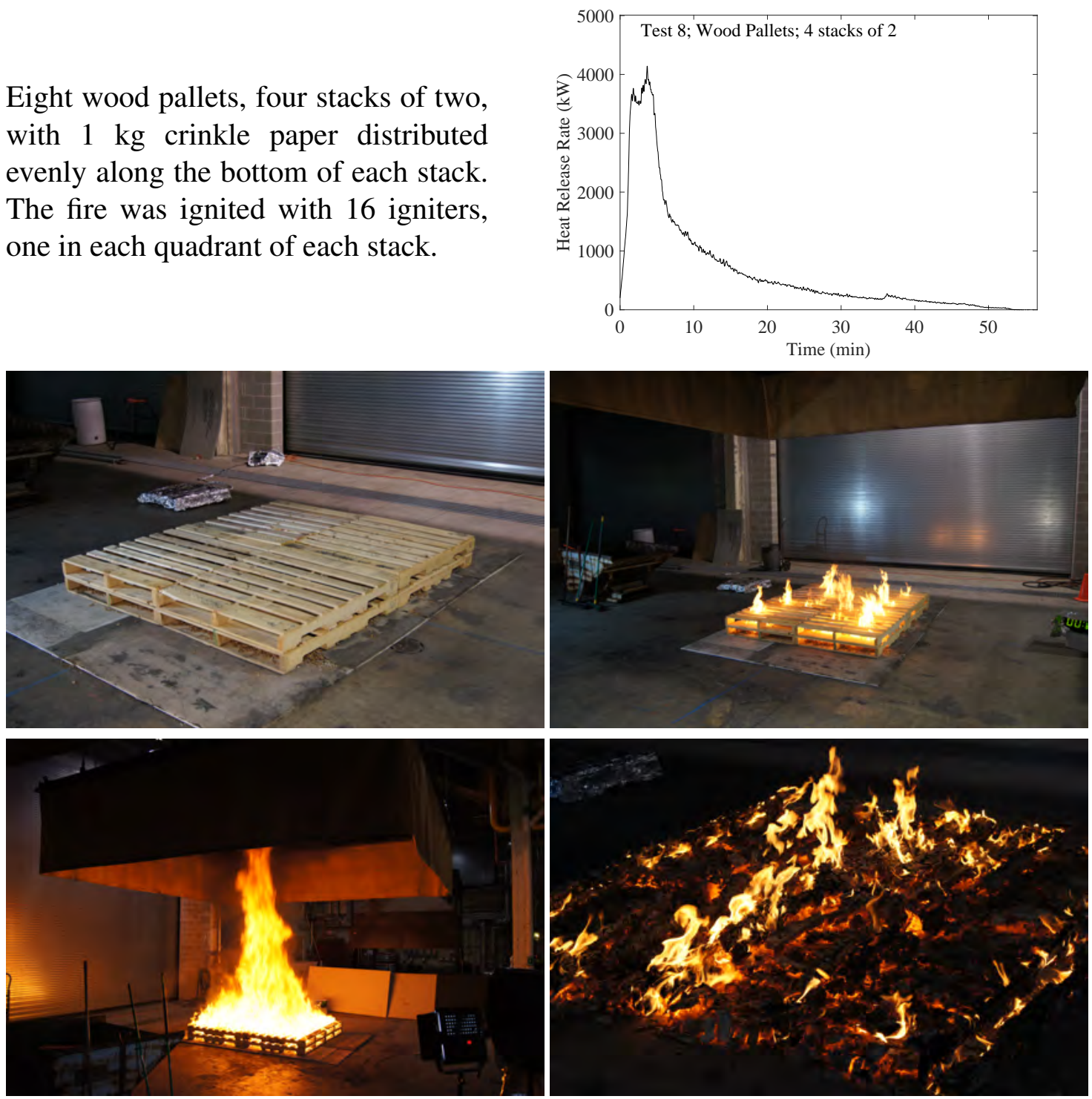

Figure 10: Heat release rate and photographs of Test 8 . 


\subsection{Test 9, Eight Pallets, One Stack}

Eight wood pallets, stacked, with $1 \mathrm{~kg}$ crinkle paper distributed evenly along the bottom of the stack. The fire was ignited with four igniters, one in each quadrant of the stack.
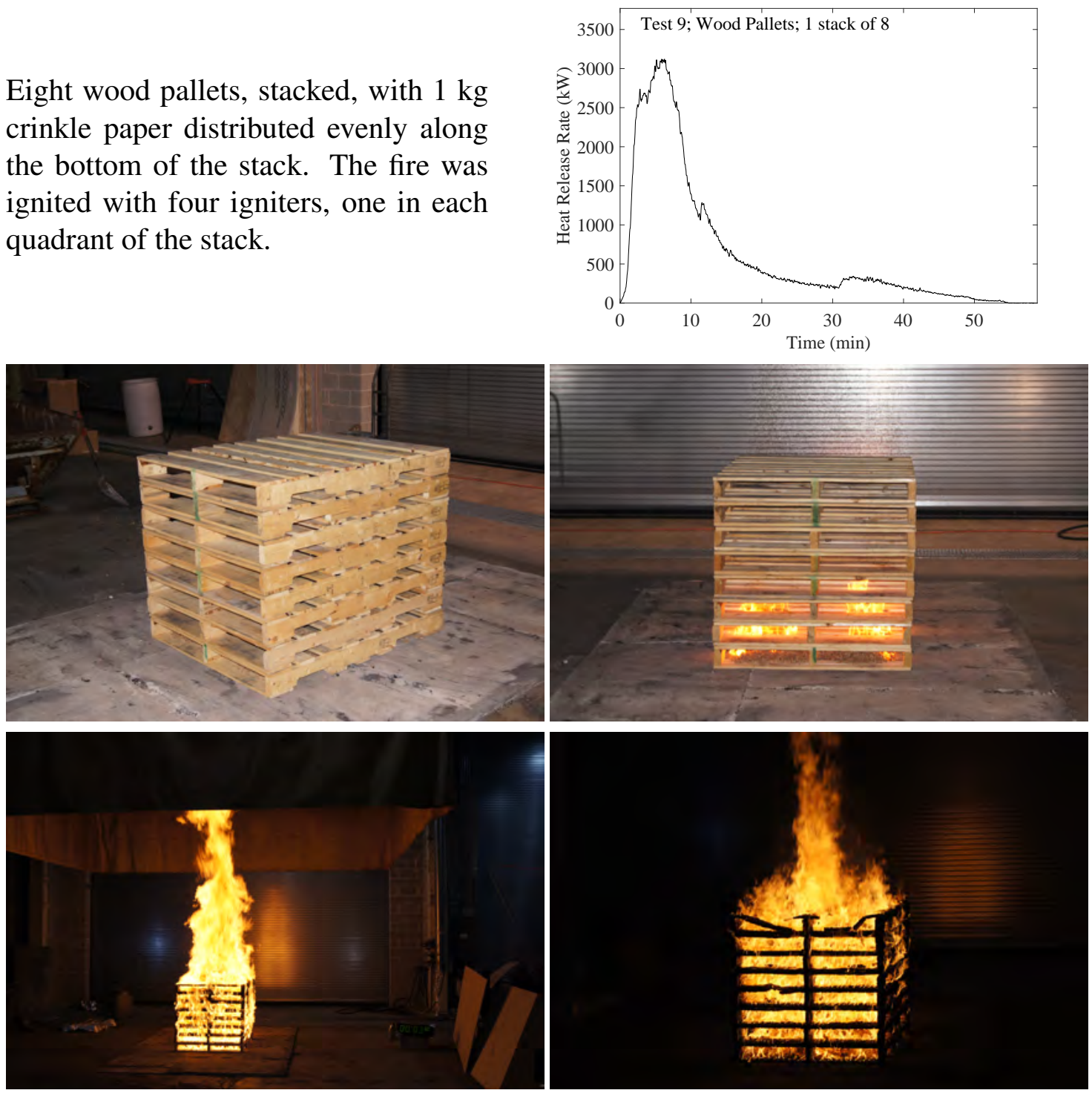

Figure 11: Heat release rate and photographs of Test 9. 


\subsection{Test 10, Single Box of Rags}

One box filled with cotton rags, ignited on four sides. The spikes in HRR after 20 min were caused by breaking up the pile of ash and debris.
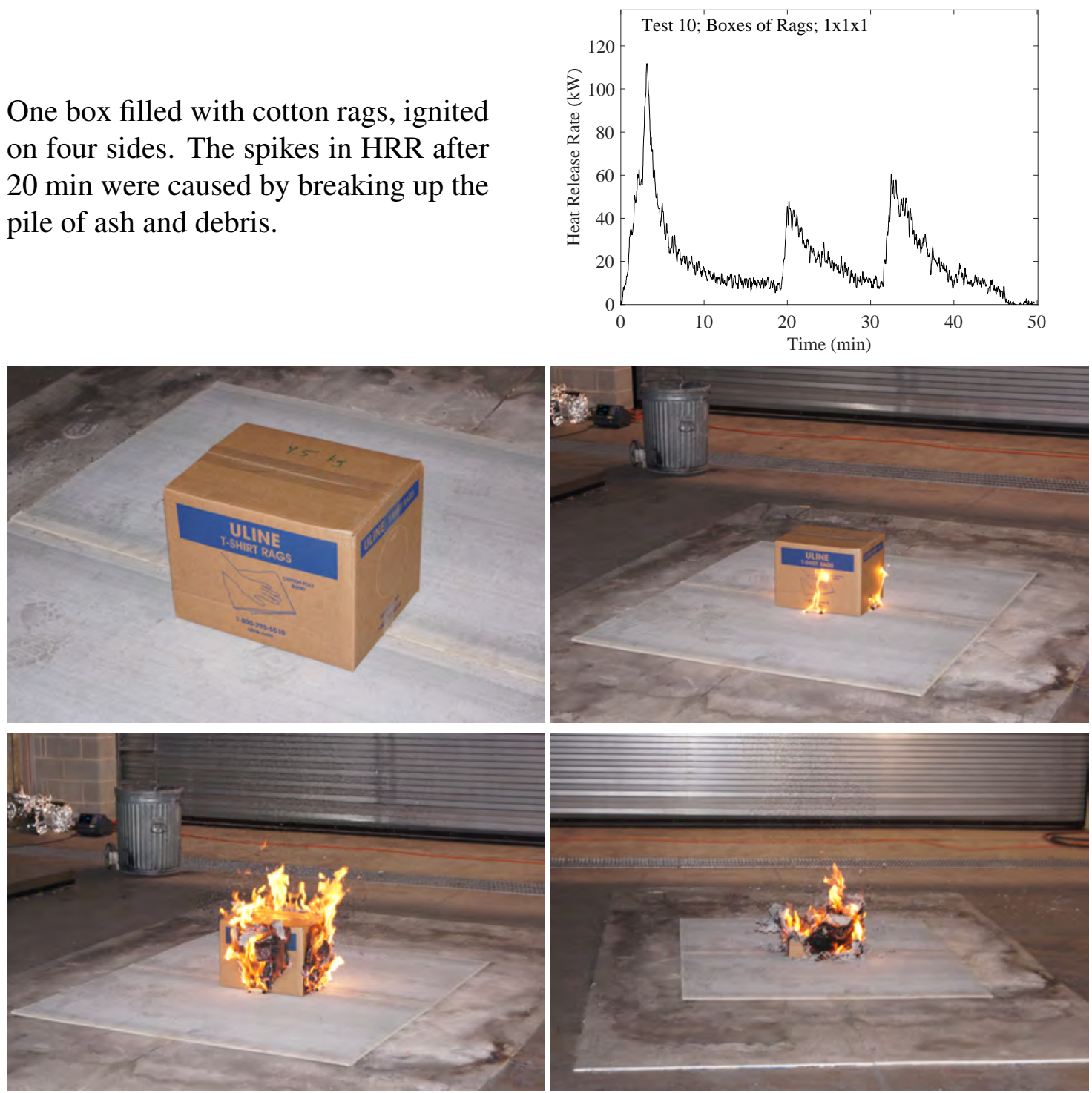

Figure 12: Heat release rate and photographs of Test 10. 


\subsection{Test 11, Four Boxes of Rags}

Four boxes filled with cotton rags, ignited at eight points. The spikes in HRR after $30 \mathrm{~min}$ were caused by breaking up the pile of ash and debris.
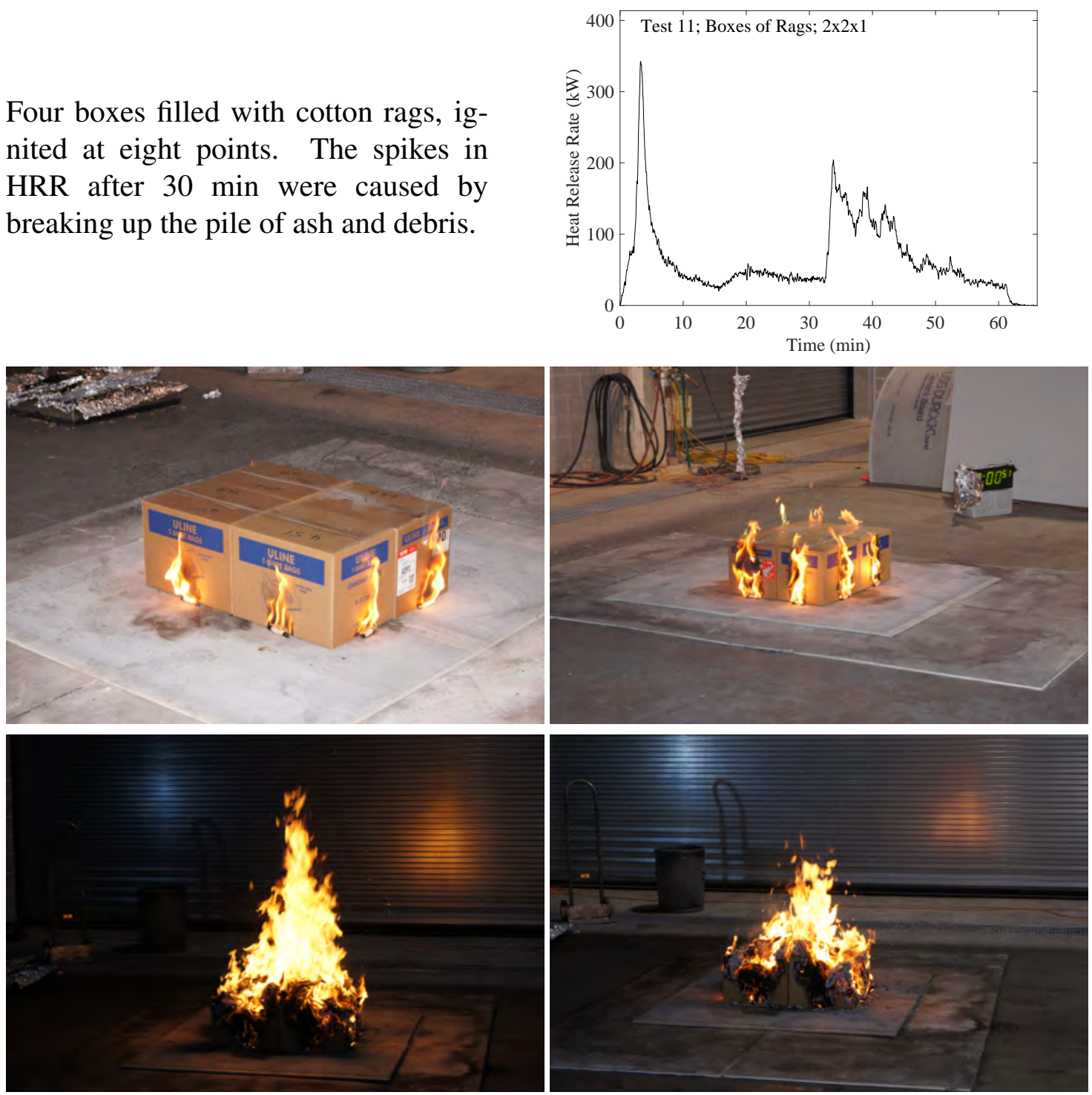

Figure 13: Heat release rate and photographs of Test 11. 


\subsection{Test 12, Four Boxes of Rags, Separated}

Four boxes filled with cotton rags, separated by a half width, ignited at eight points. The spikes in HRR after $30 \mathrm{~min}$ were caused by breaking up the pile of ash and debris.
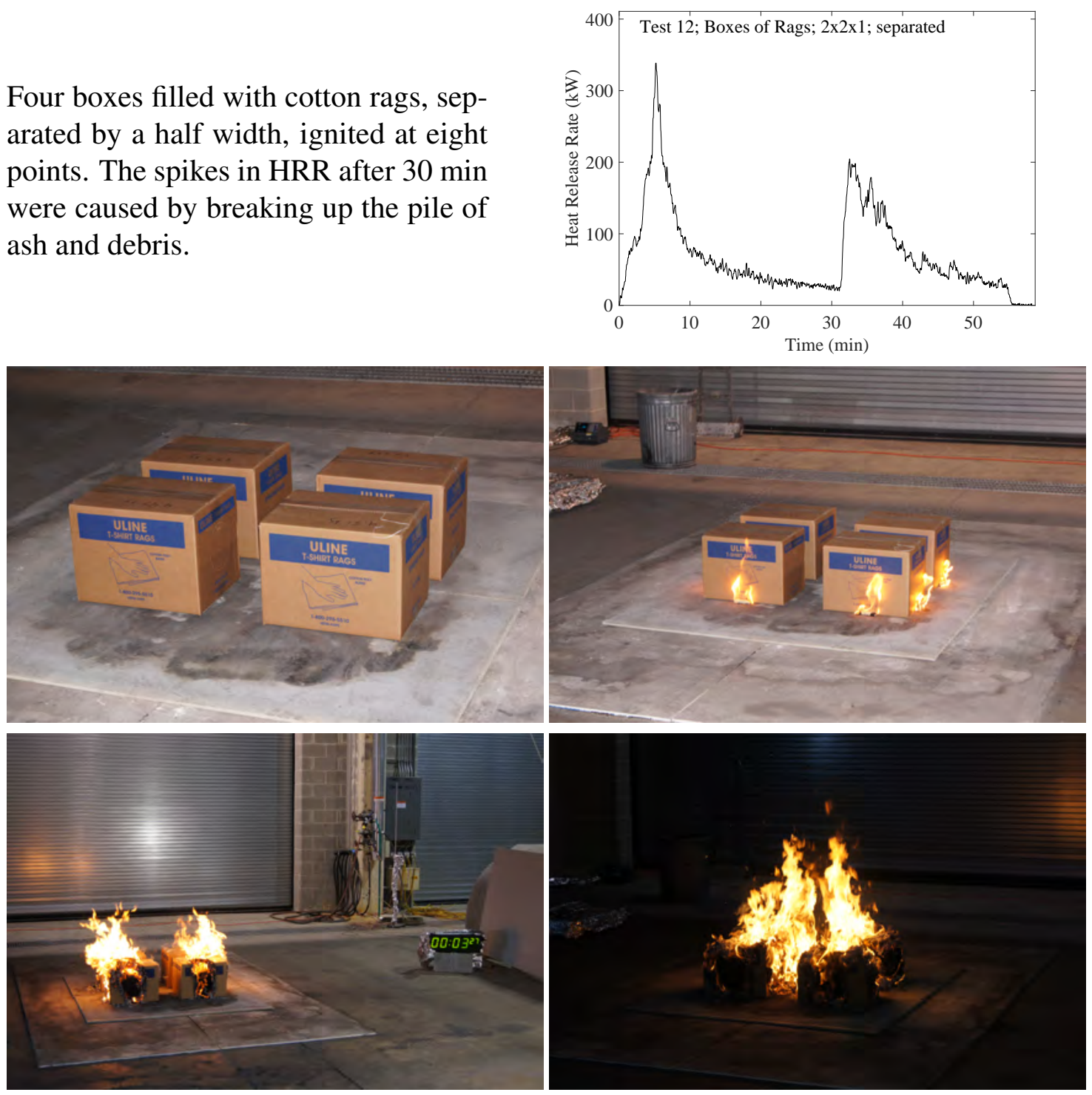

Figure 14: Heat release rate and photographs of Test 12. 


\subsection{Test 13, Single Wood Crib}

Single wood crib with $0.75 \mathrm{~kg}$ crinkle paper evenly distributed at the base and ignited at two points. At approximately $48 \mathrm{~min}$, the hot coals were spread out and raked into a water bath.
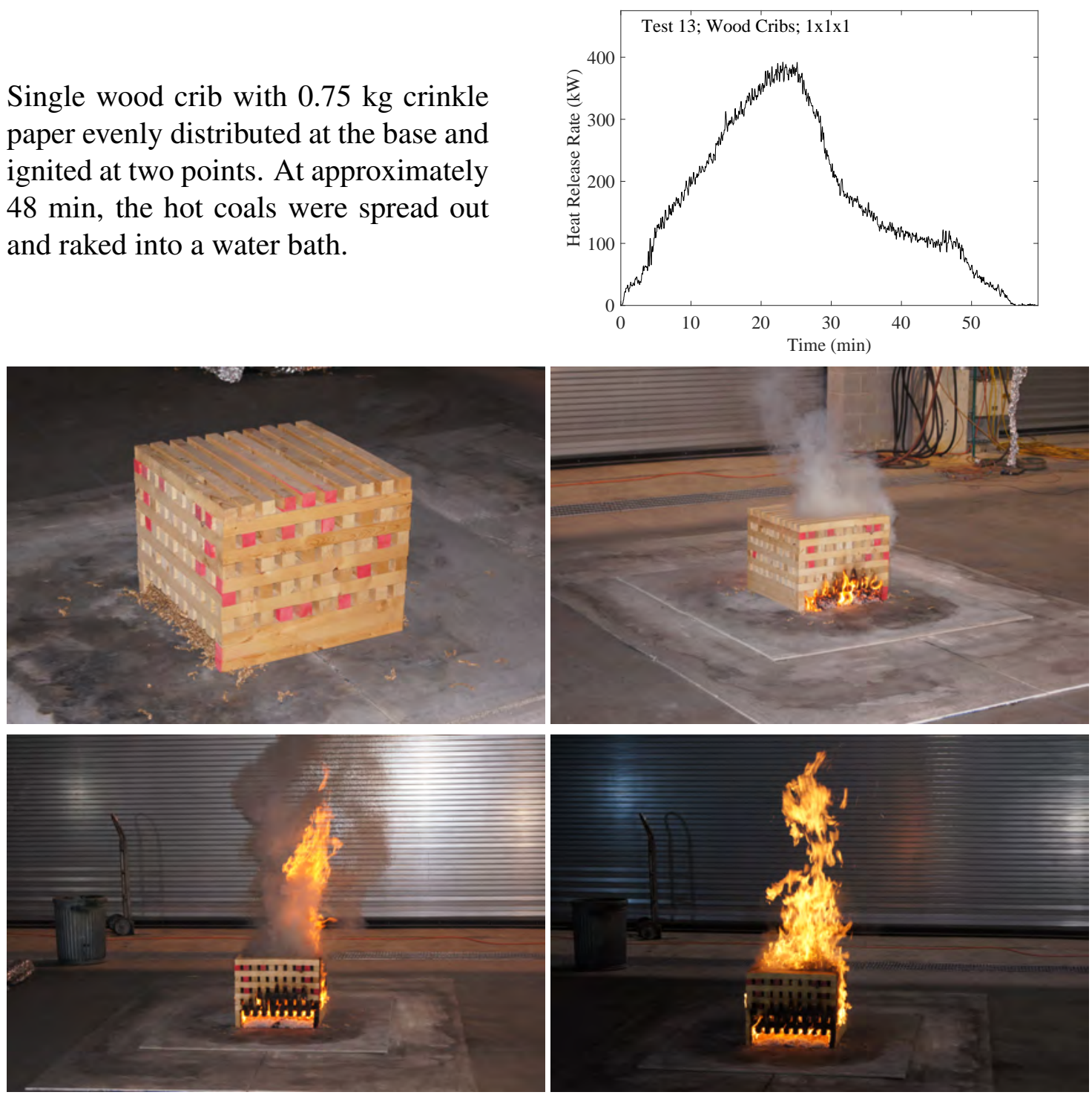

Figure 15: Heat release rate and photographs of Test 13. 


\subsection{Test 14, Two Wood Cribs, Side by Side}
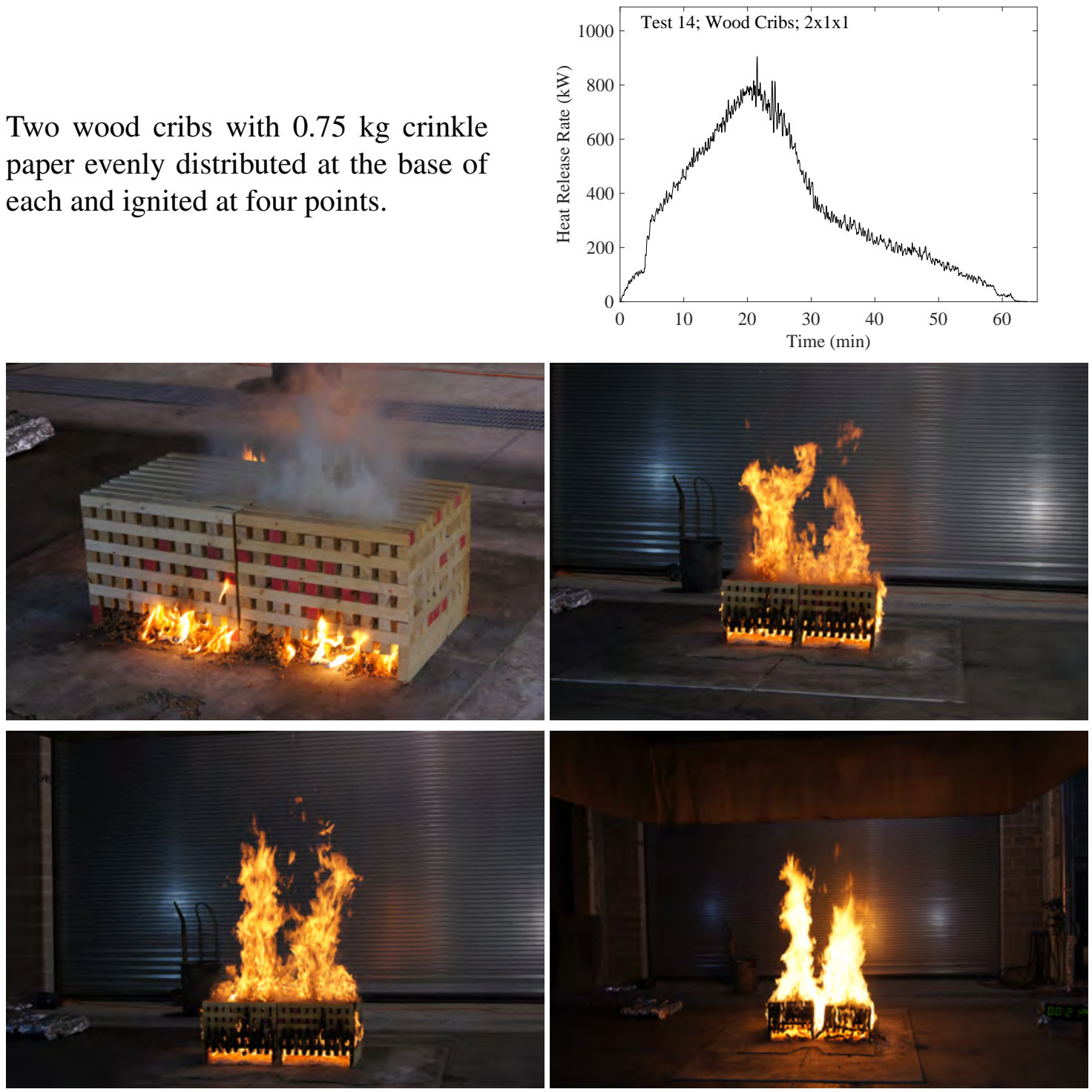

Figure 16: Heat release rate and photographs of Test 14. 


\subsection{Test 15, Four Wood Cribs, Two by Two Array}

Four wood cribs with $0.75 \mathrm{~kg}$ crinkle paper evenly distributed at the base of each and ignited at four points. At approximately $60 \mathrm{~min}$, the hot coals were spread out and at 80 min raked into a water bath.
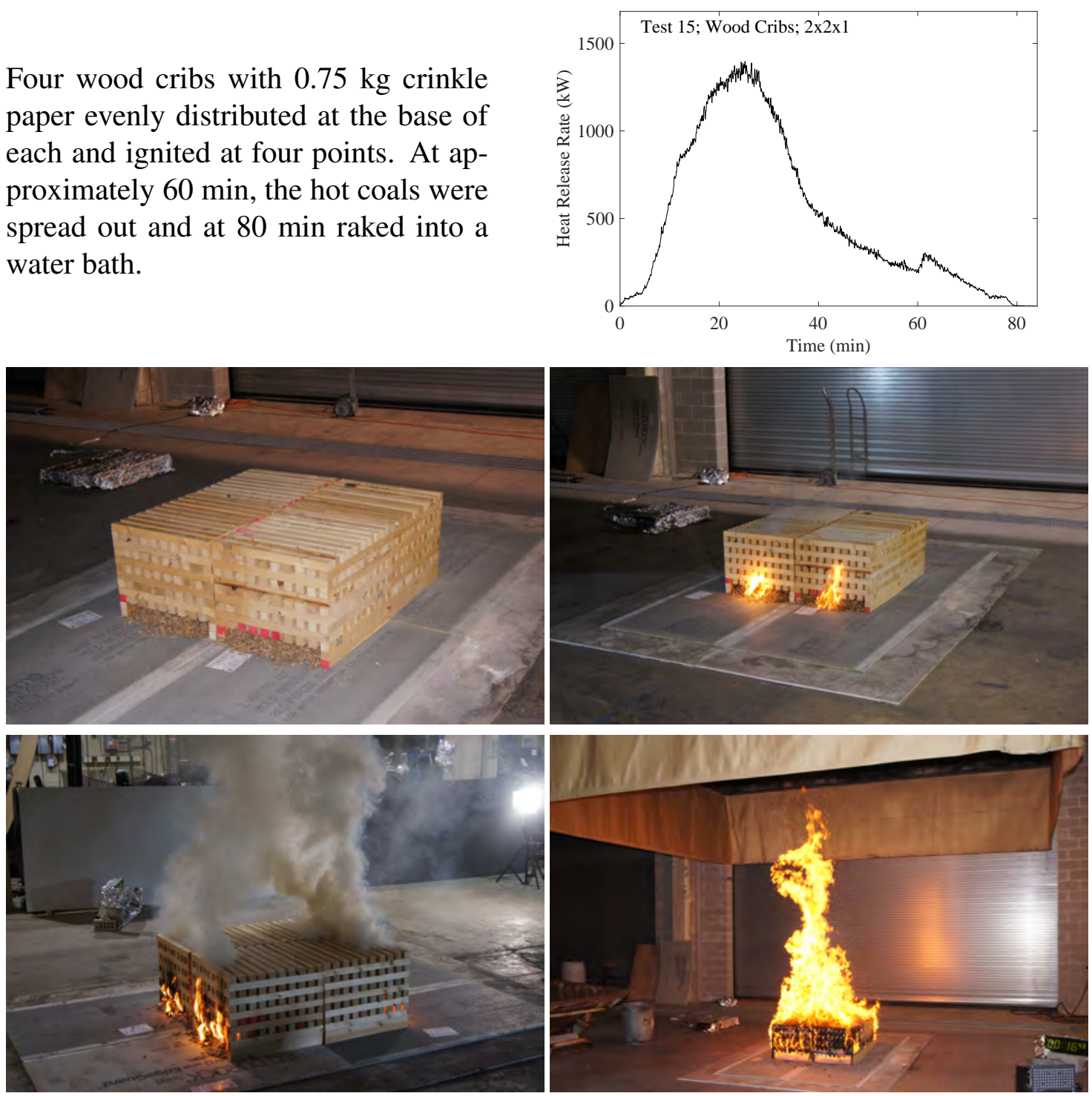

Figure 17: Heat release rate and photographs of Test 15. 


\subsection{Test 16, Eight Wood Cribs, Four Stacks of Two}

Eight wood cribs, four stacks of two, with $0.75 \mathrm{~kg}$ crinkle paper evenly distributed at the base of each stack and ignited at four points.
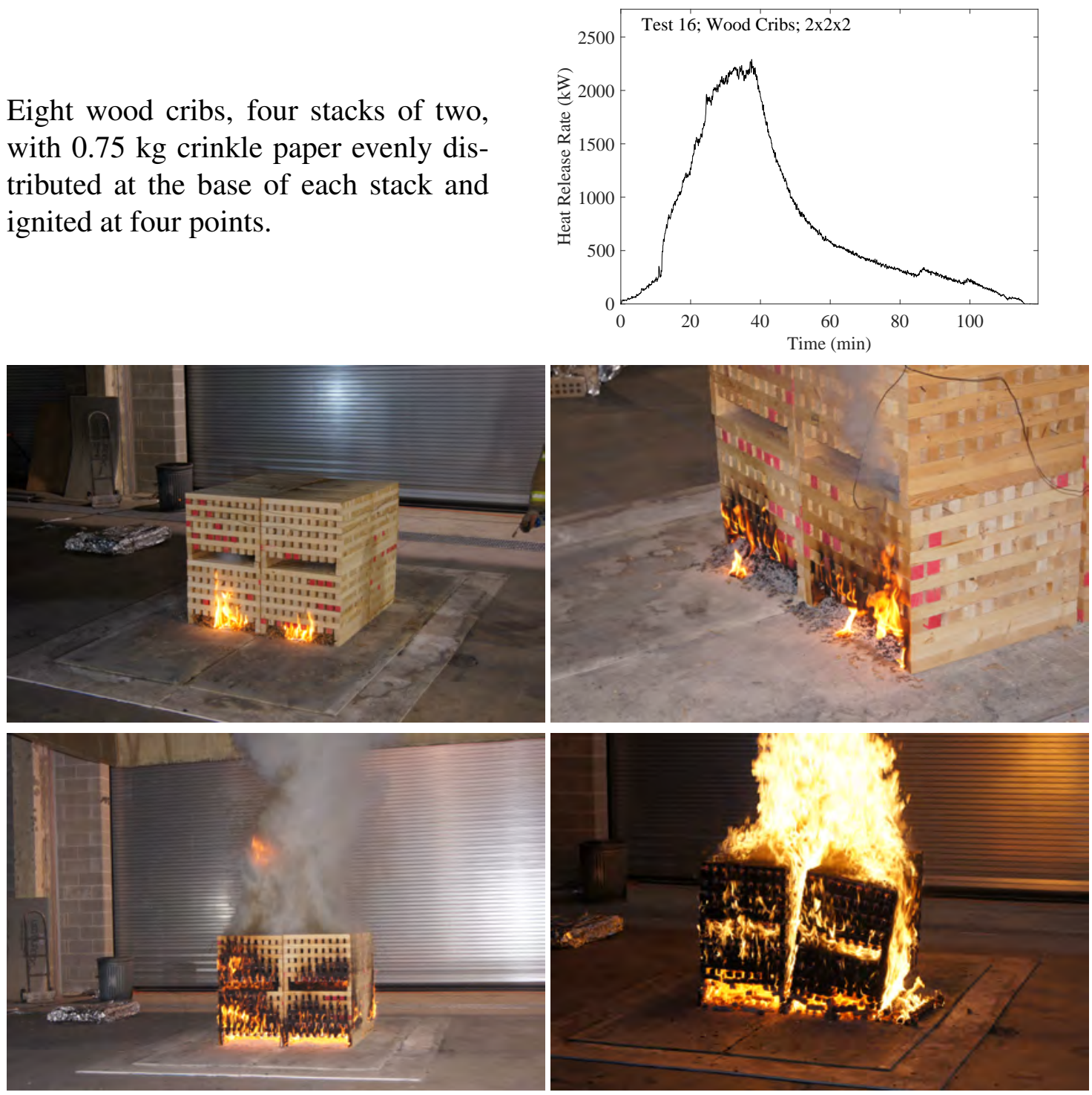

Figure 18: Heat release rate and photographs of Test 16. 


\subsection{Test 17, Single Plastic Trash Bin Filled with Crinkle Paper}
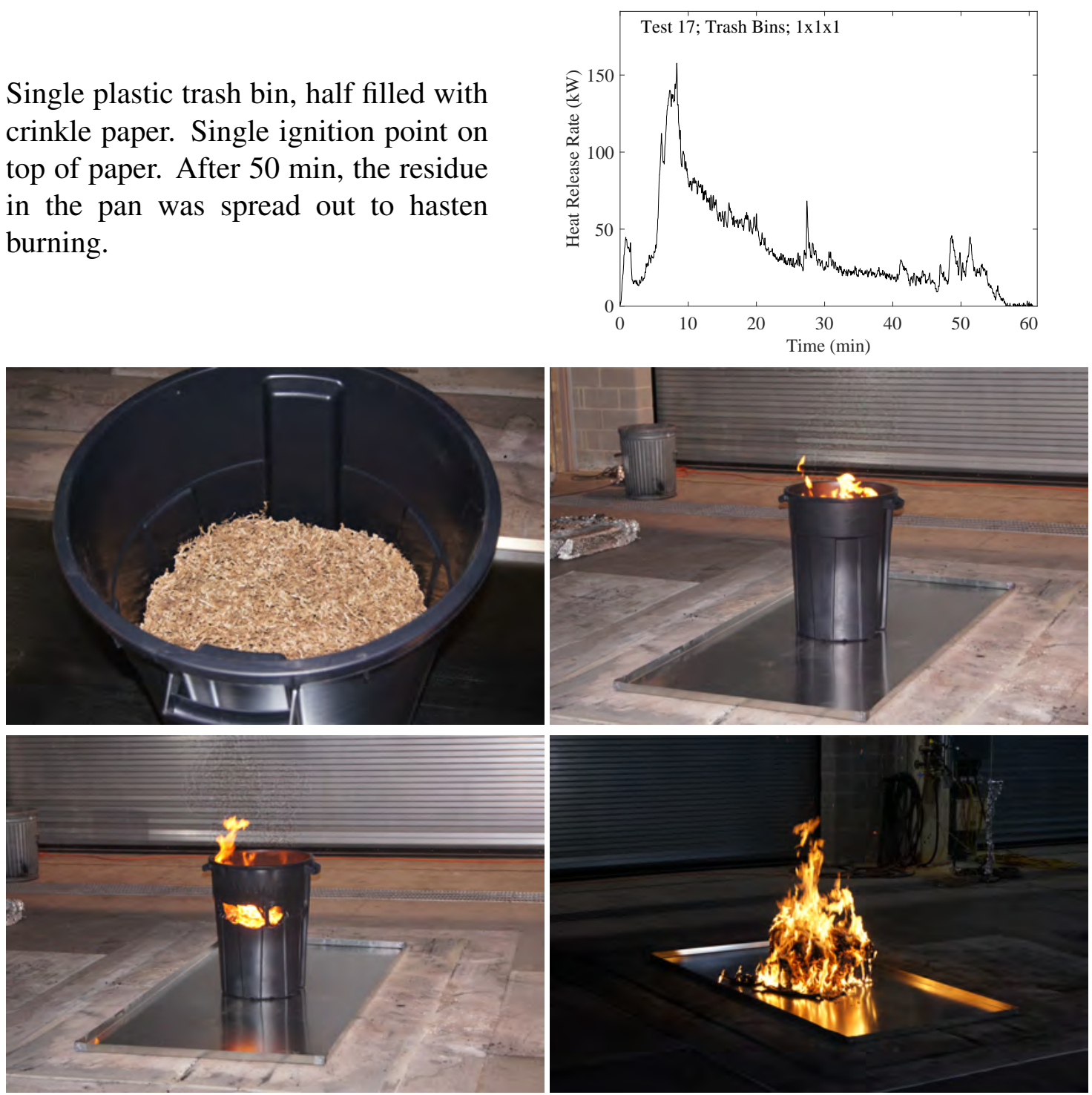

Figure 19: Heat release rate and photographs of Test 17. 


\subsection{Test 18, Two Plastic Trash Bins Filled with Crinkle Paper}

Two plastic trash bins, half filled with crinkle paper. Single ignition point on top of paper in each bin. After $20 \mathrm{~min}$, the residue in the pan was spread out to hasten burning.
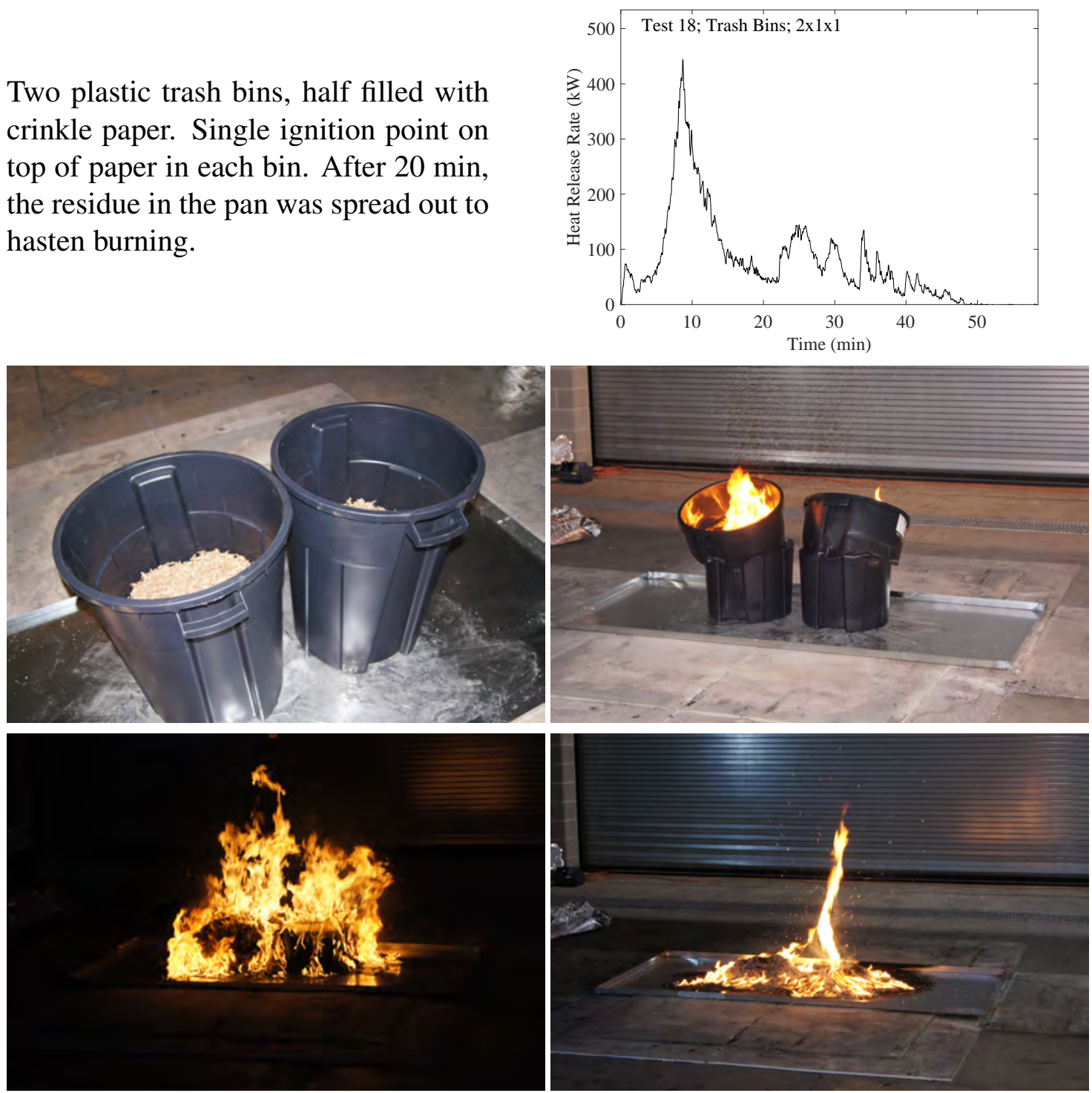

Figure 20: Heat release rate and photographs of Test 18. 


\subsection{Test 19, Four Plastic Trash Bins Filled with Crinkle Paper}

Four plastic trash bins, half filled with crinkle paper. Single ignition point on top of paper in each bin. The bins are wired together to ensure that the melt remains in the catch pan. After $40 \mathrm{~min}$, the residue in the pan was spread out to hasten burning.
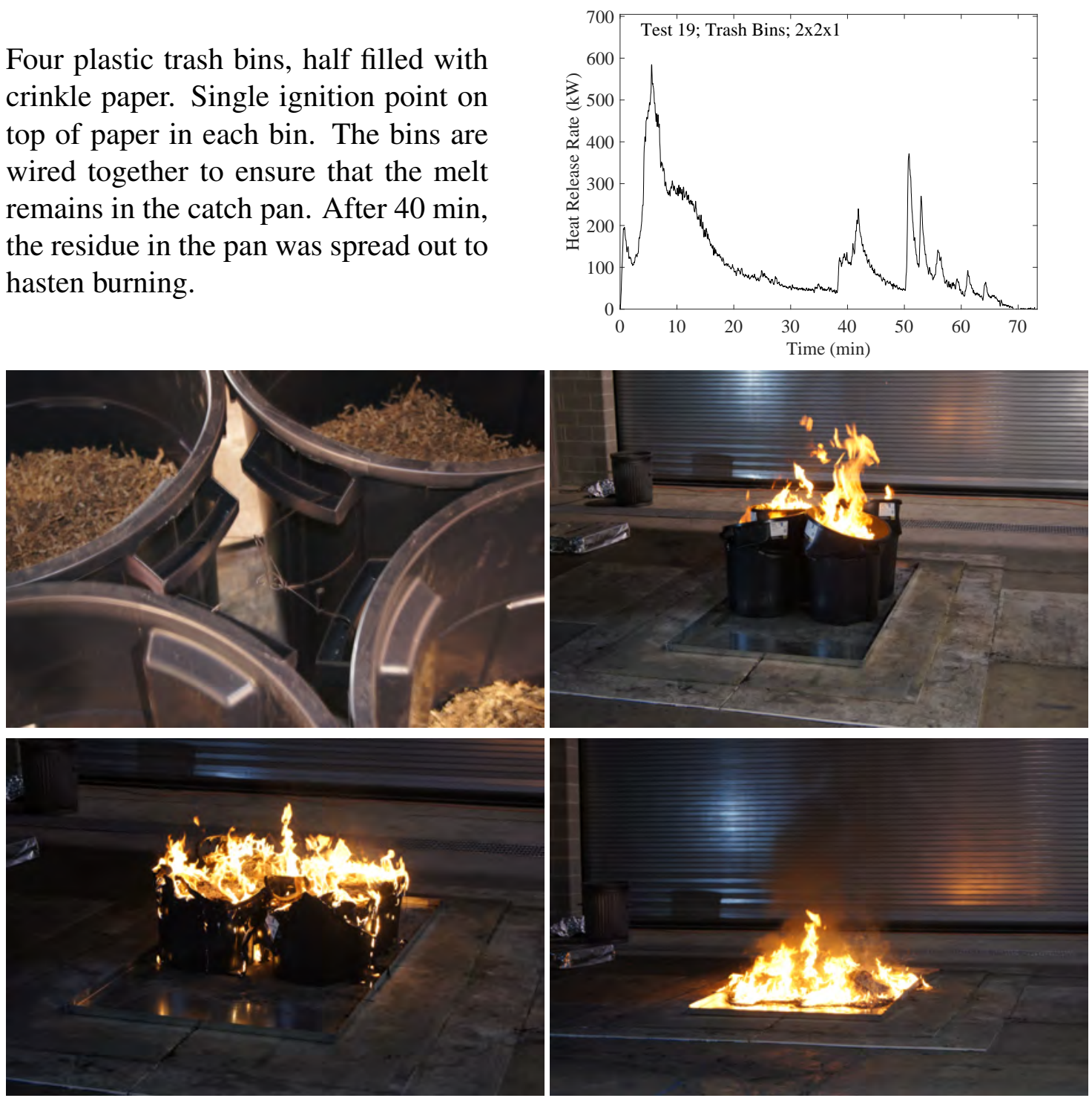

Figure 21: Heat release rate and photographs of Test 19. 


\subsection{Test 20, Four Plastic Trash Bins Filled with Crinkle Paper Atop Two Pallets}

Four plastic trash bins, half filled with crinkle paper, atop two pallets. Single ignition point on top of paper in each bin and four ignition points in each quadrant of the pallet stack. The bins were wired together to ensure that the melt remains in the catch pan.
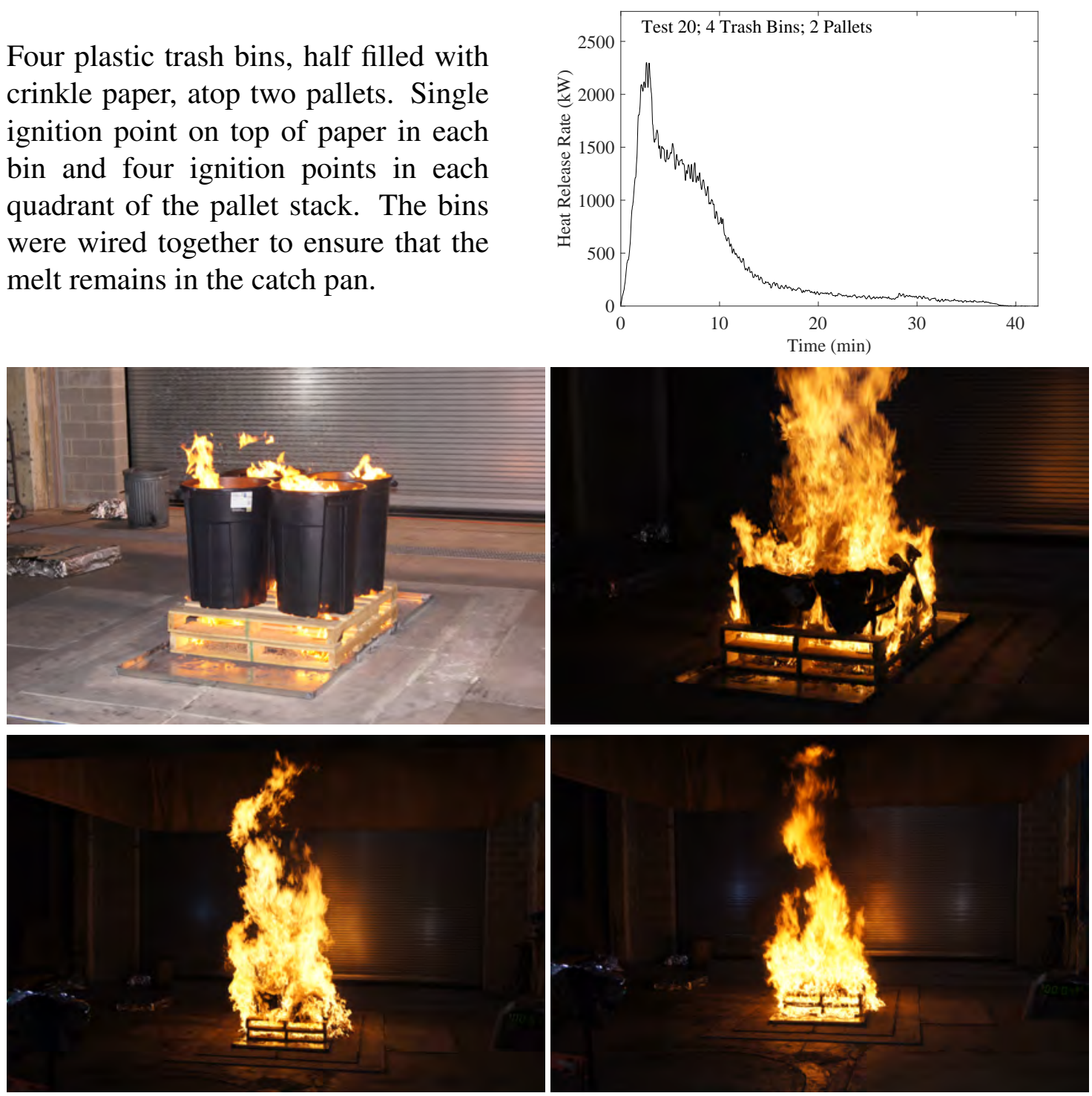

Figure 22: Heat release rate and photographs of Test 20. 


\subsection{Test 21, Eight Boxes Filled with Crinkle Paper Atop Two Pallets}
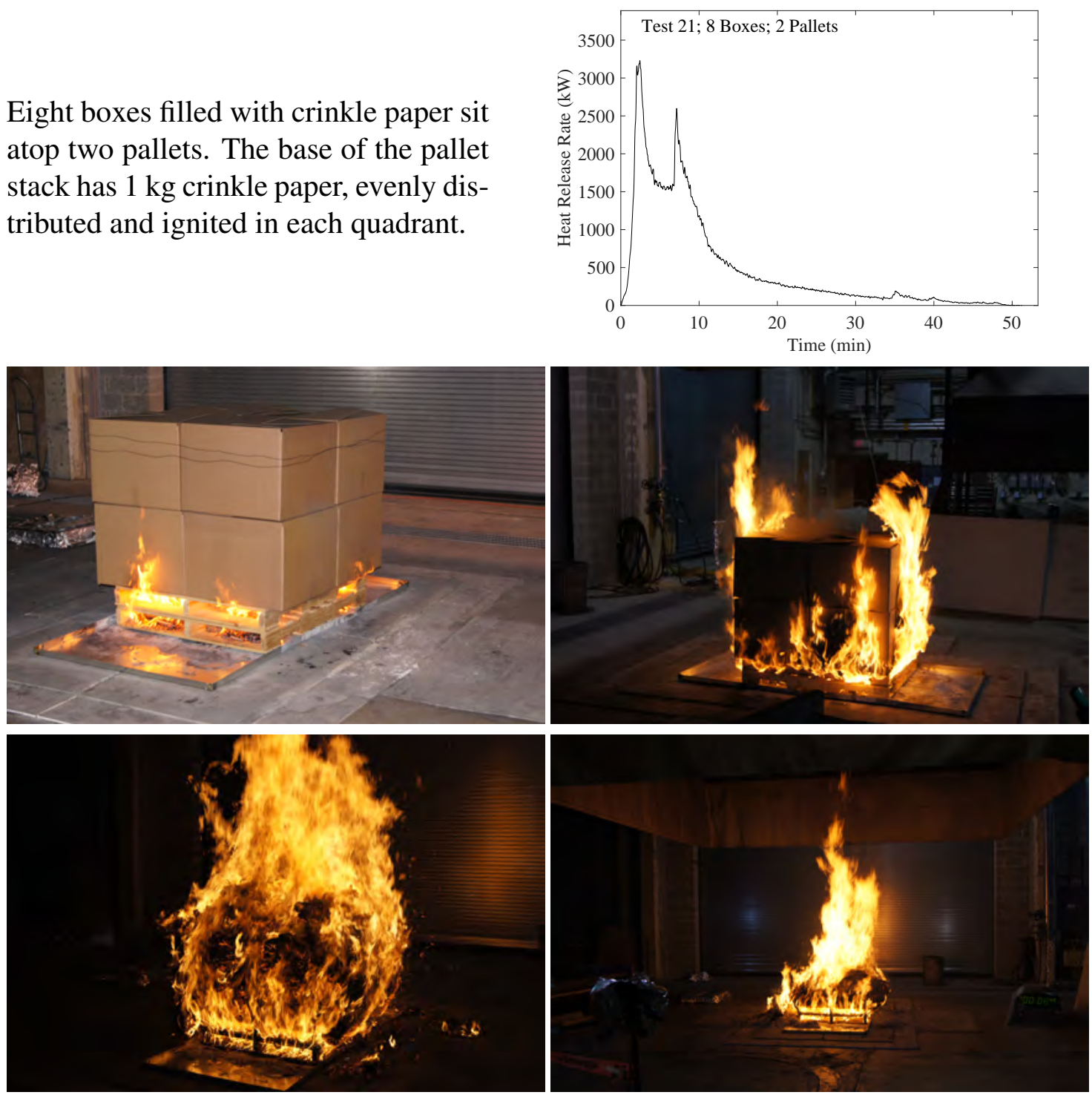

Figure 23: Heat release rate and photographs of Test 21. 


\subsection{Test 22, Single Hanging Plastic Tarp}

A single plastic tarp, initially hanging $30 \mathrm{~cm}(1 \mathrm{ft})$ above the floor, ignited in two locations. The fire spread slowly and erratically.
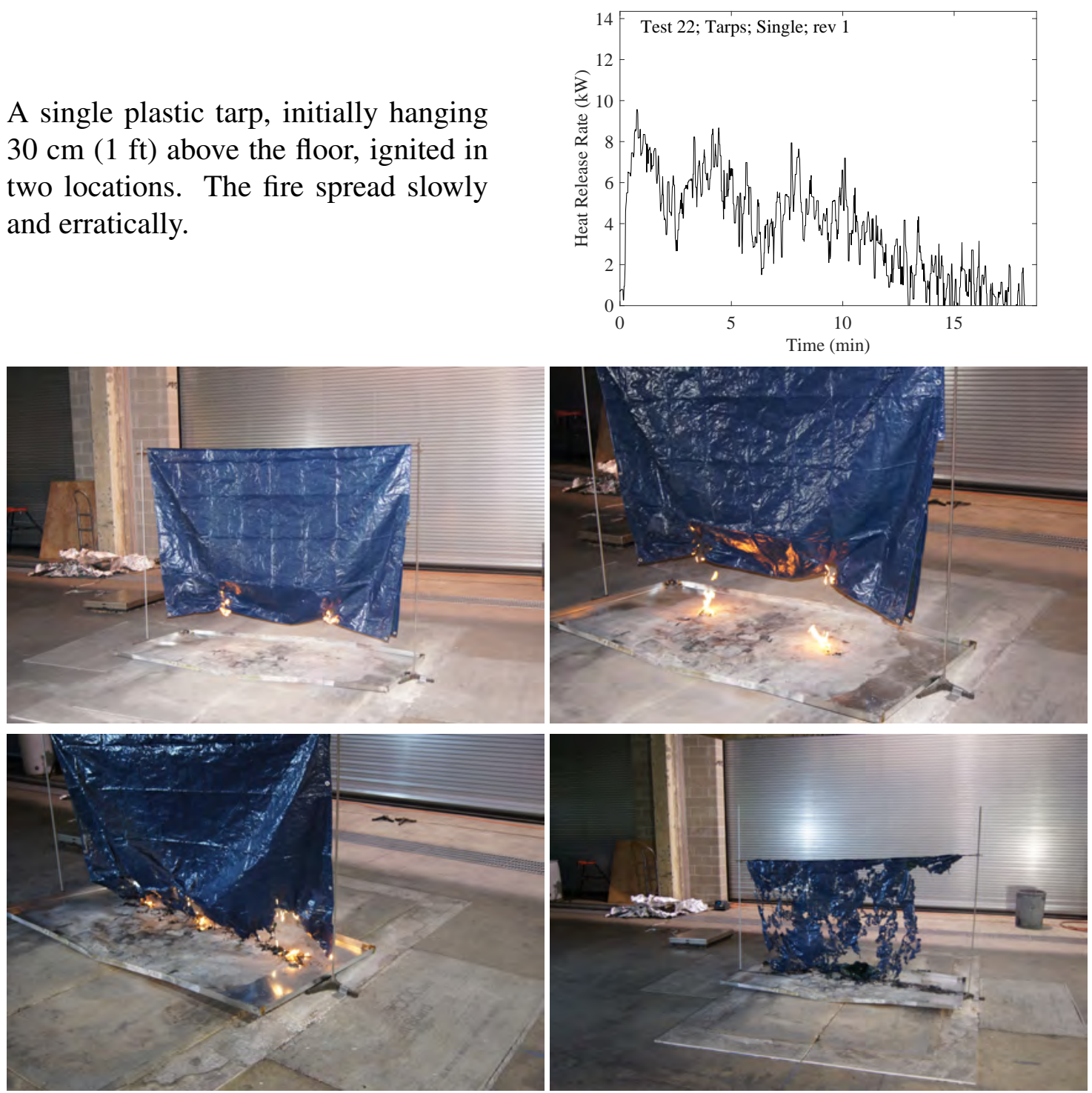

Figure 24: Heat release rate and photographs of Test 22. 


\subsection{Test 23, Single Hanging Plastic Tarp, Replicate 2}

A single plastic tarp, with $15 \mathrm{~cm}$ (6 in) dragging on floor, ignited in two locations. The fire spread slowly and erratically.
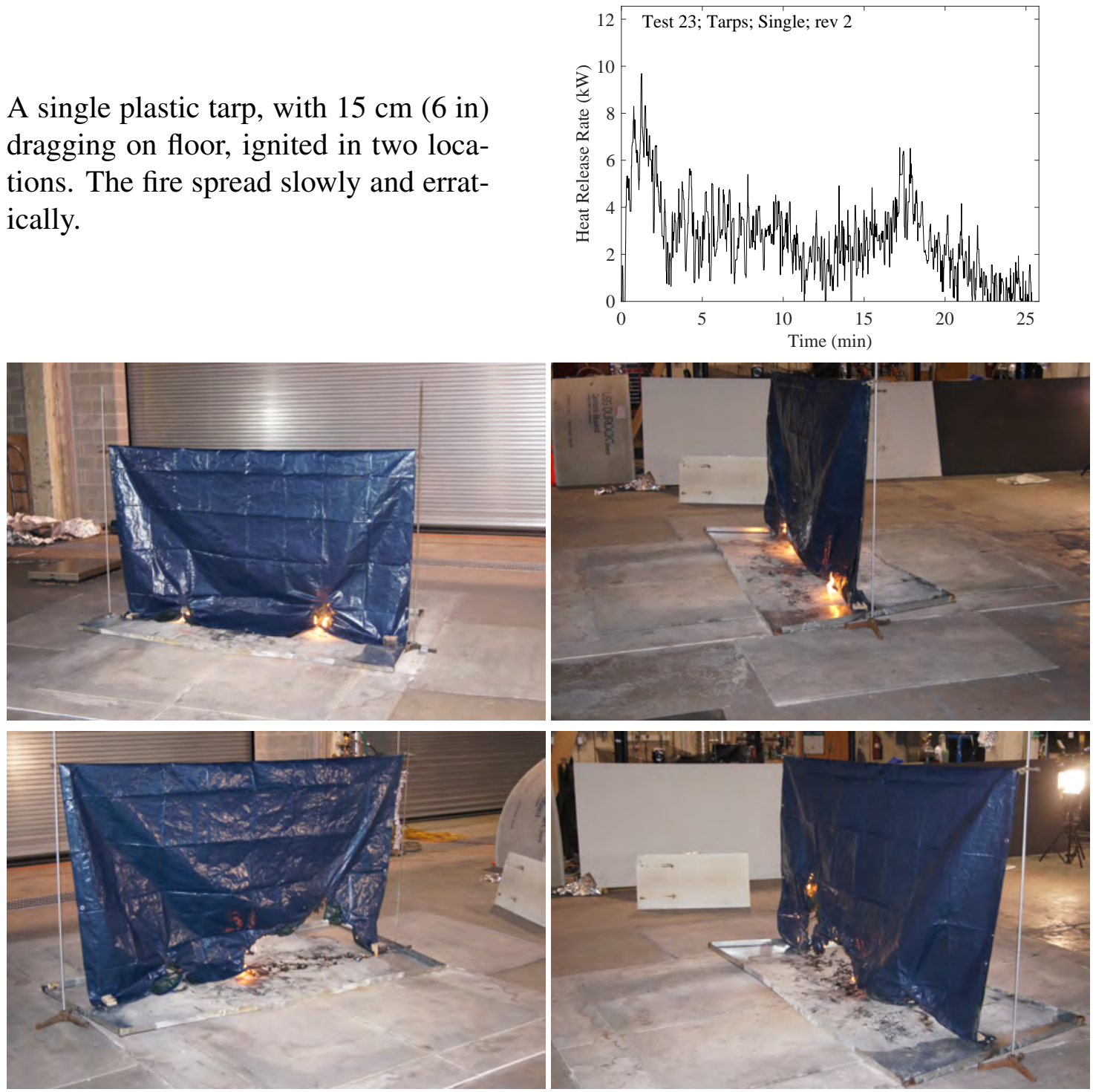

Figure 25: Heat release rate and photographs of Test 23. 


\subsection{Test 24, Two Hanging, Overlapping Plastic Tarps}
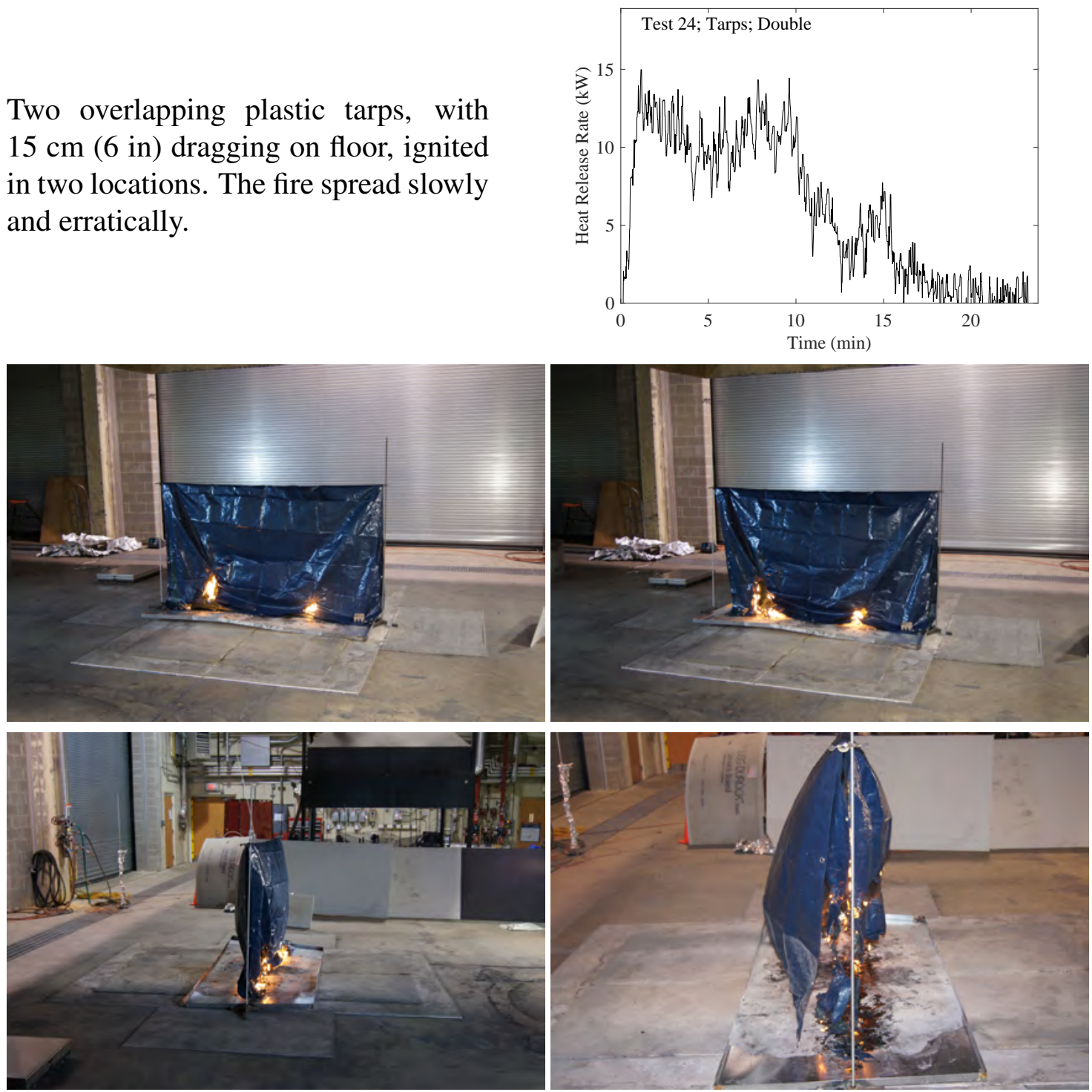

Figure 26: Heat release rate and photographs of Test 24. 


\subsection{Test 25, Single Box, Plastic Commodity}
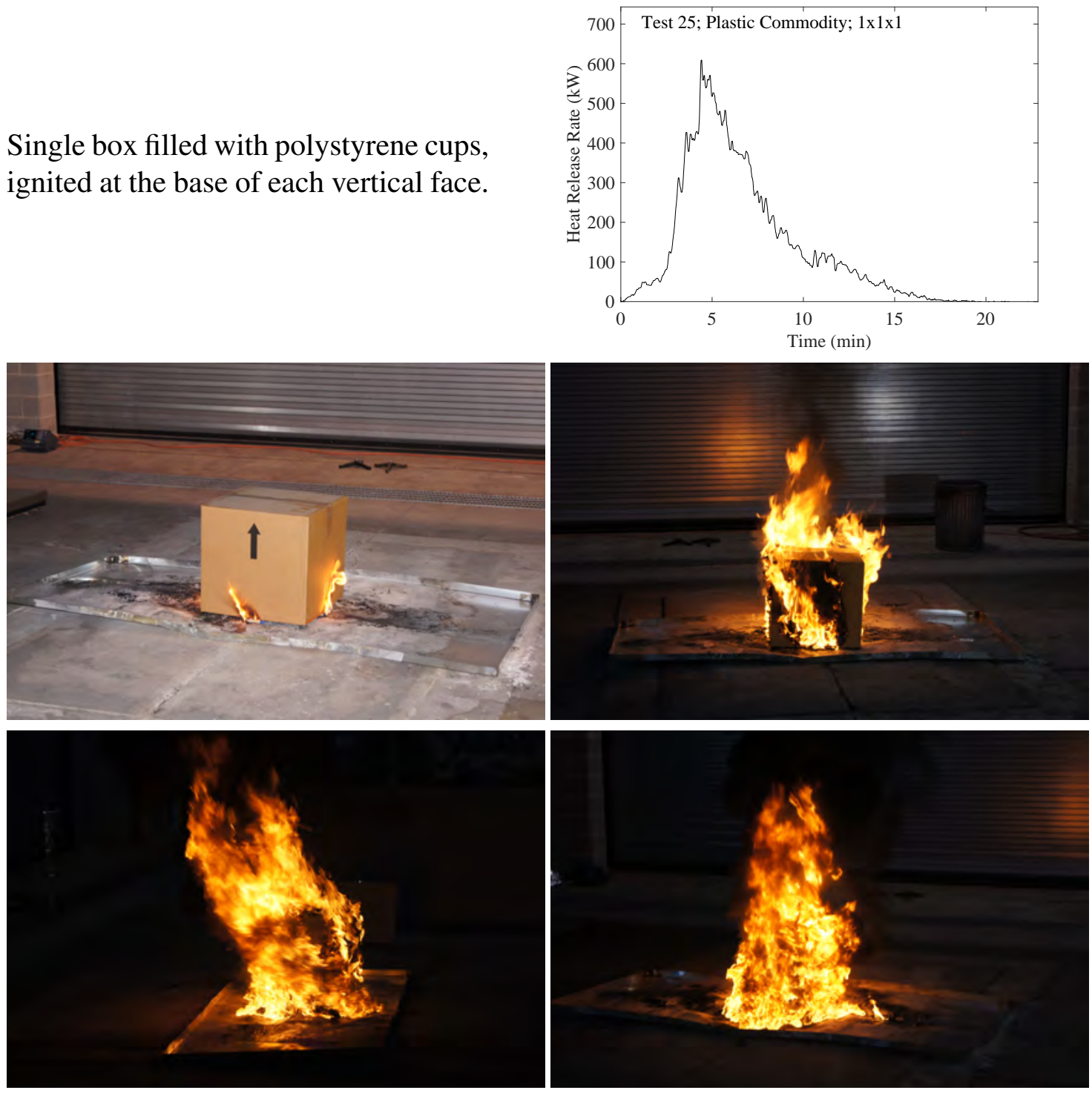

Figure 27: Heat release rate and photographs of Test 25. 


\subsection{Test 26, Two Boxes, Plastic Commodity}
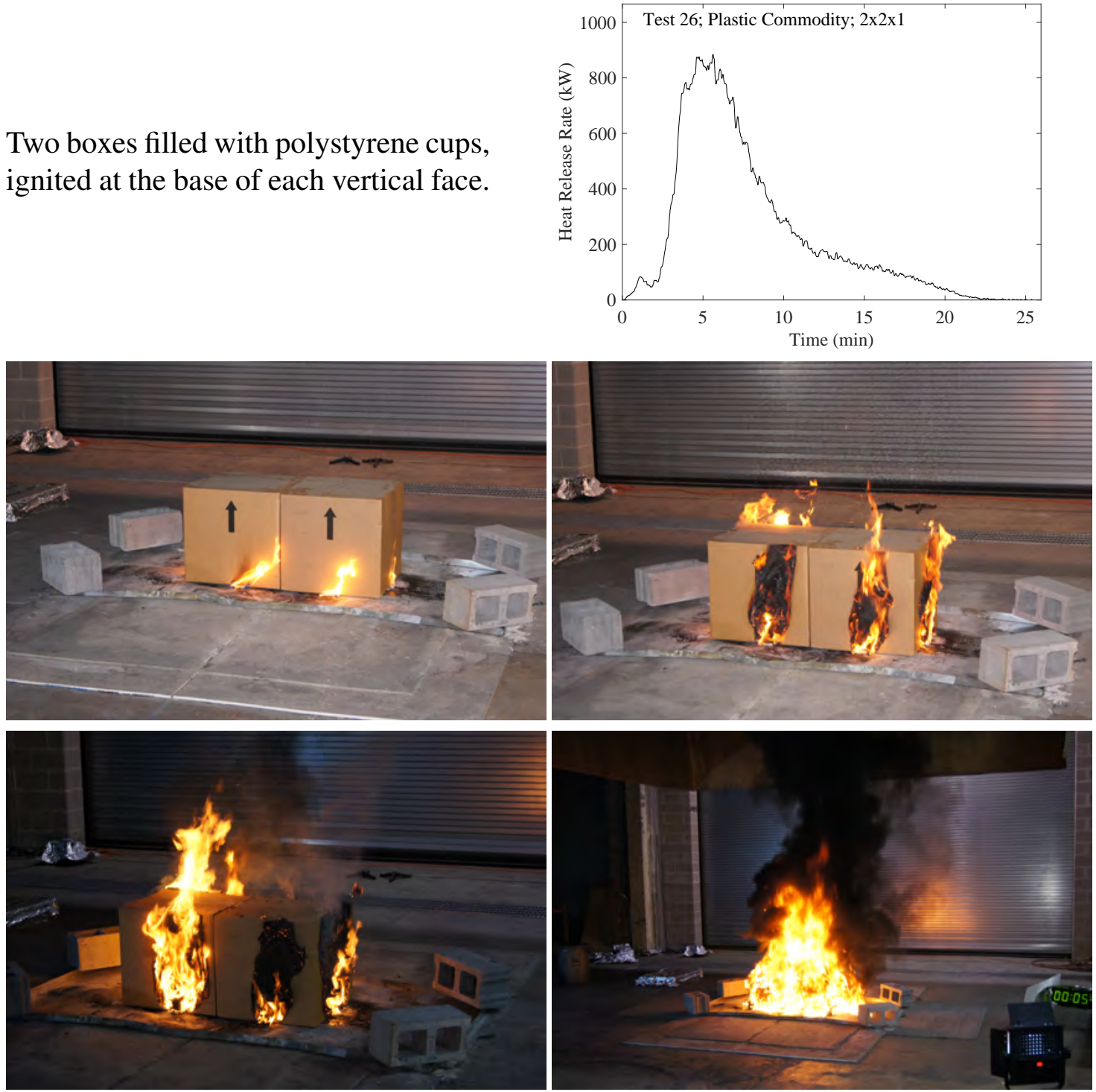

Figure 28: Heat release rate and photographs of Test 26. 


\subsection{Test 27, Four Boxes, Plastic Commodity}
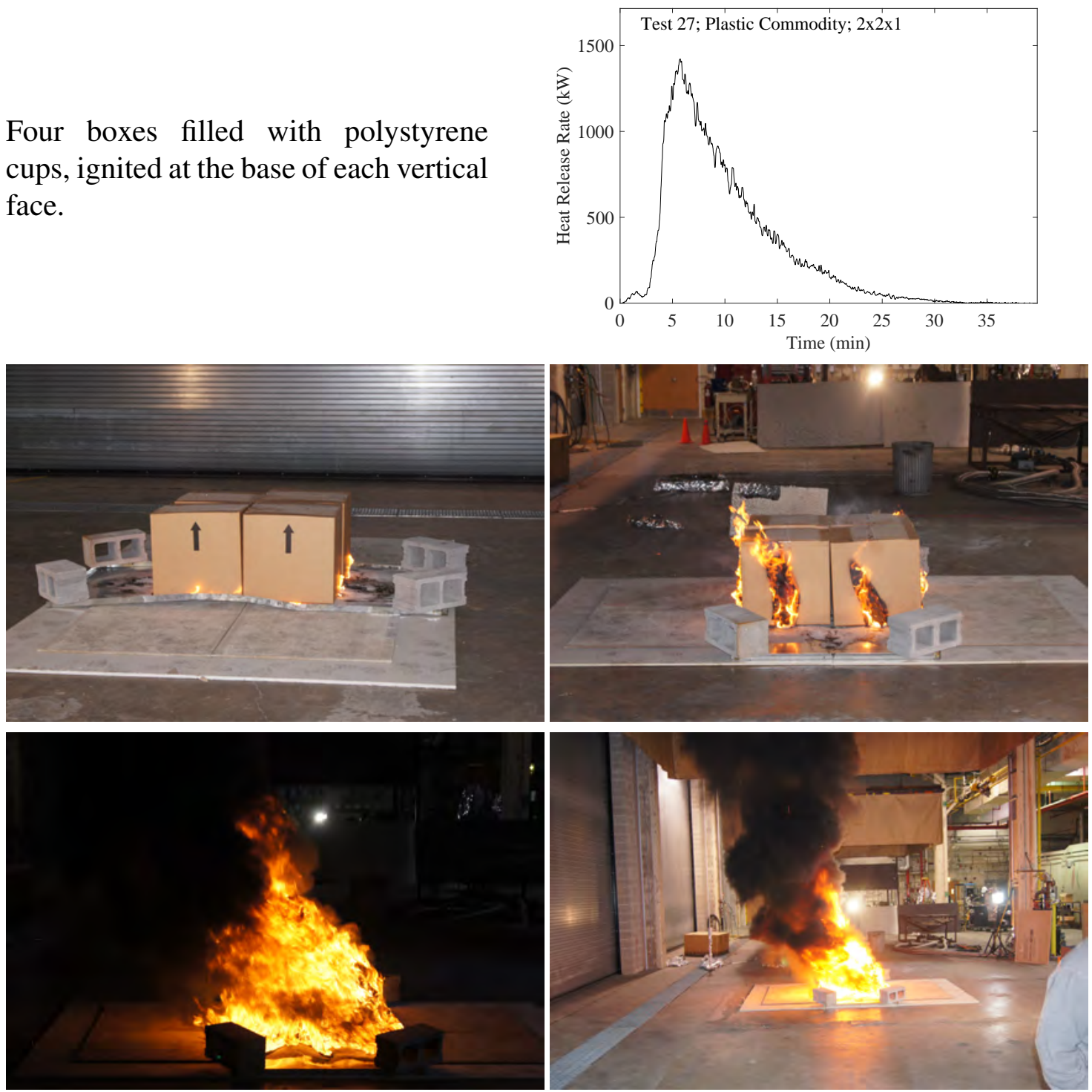

Figure 29: Heat release rate and photographs of Test 27. 


\subsection{Test 28, Eight Boxes, Plastic Commodity}
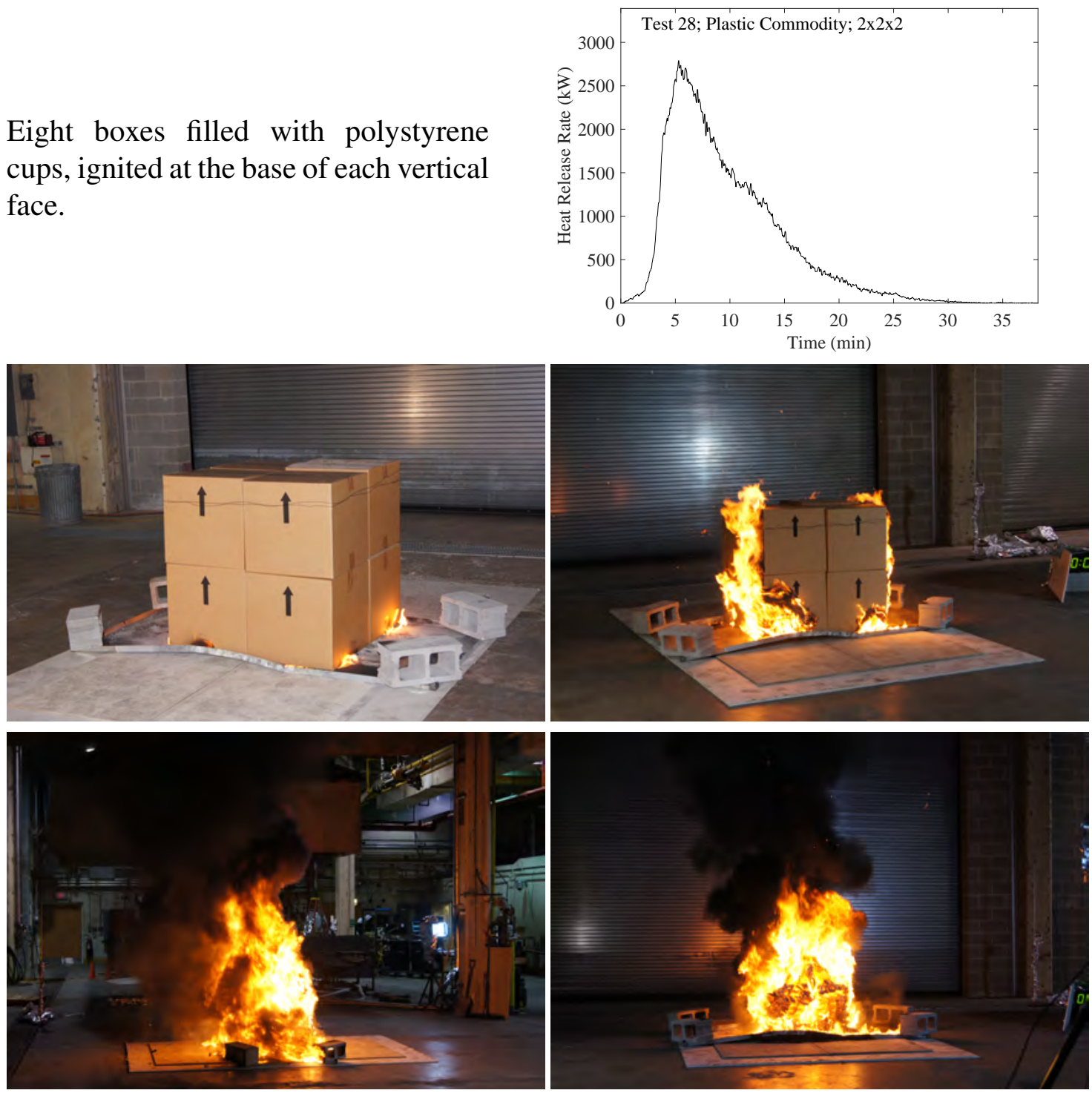

Figure 30: Heat release rate and photographs of Test 28. 


\subsection{Test 29, Single Plastic Bin Filled with Rags and Paper}

Single plastic bin with the same amount of crinkle paper as in Test 17, along with the entire box and rags of Test 10. Single ignition point on top of paper and rags.
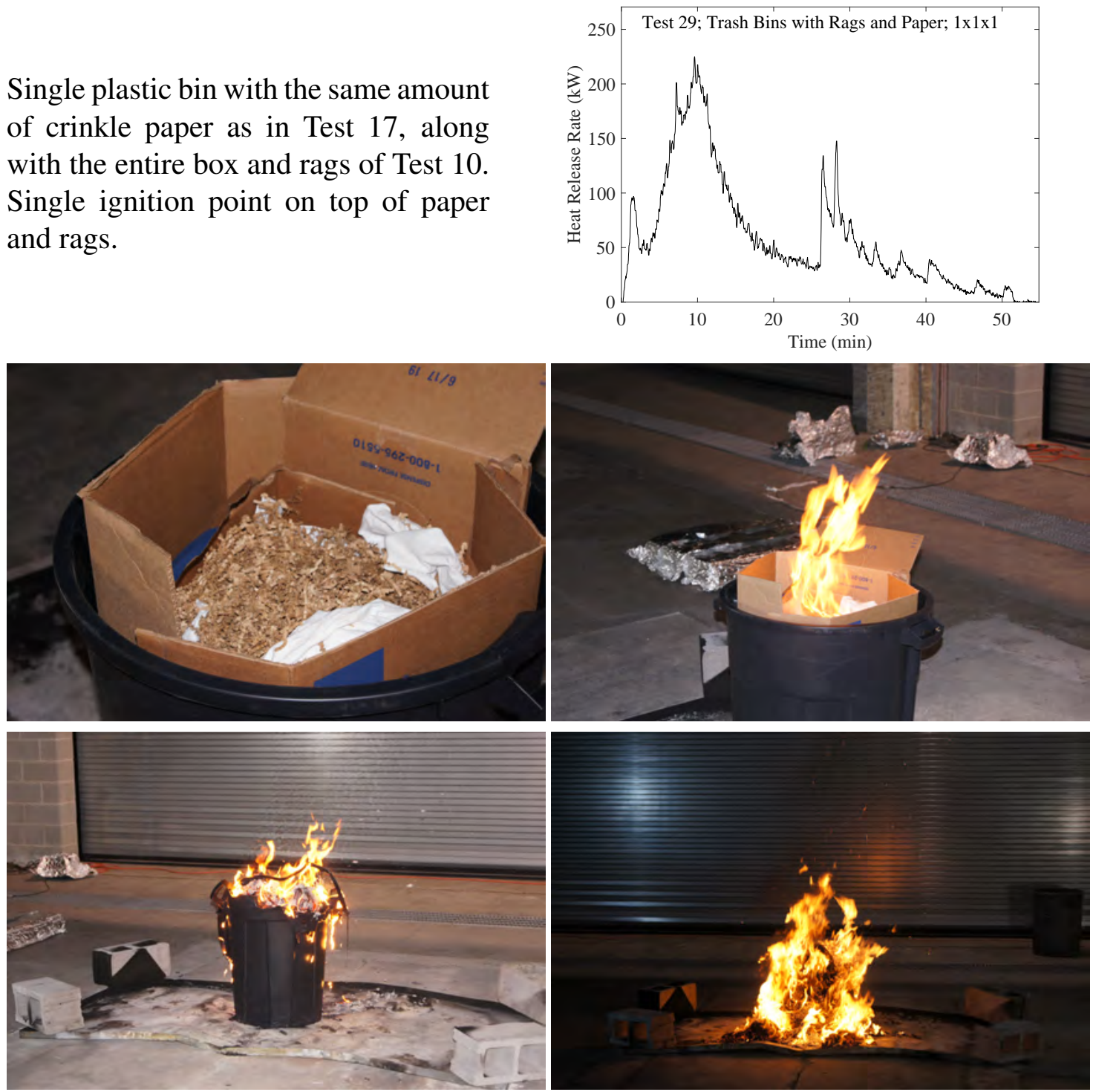

Figure 31: Heat release rate and photographs of Test 29. 


\subsection{Test 30, Two Plastic Bins Filled with Rags and Paper}

Two plastic bins with the same amount of crinkle paper as in Test 17, along with the entire box and rags of Test 10. Single ignition points on top of paper and rags.
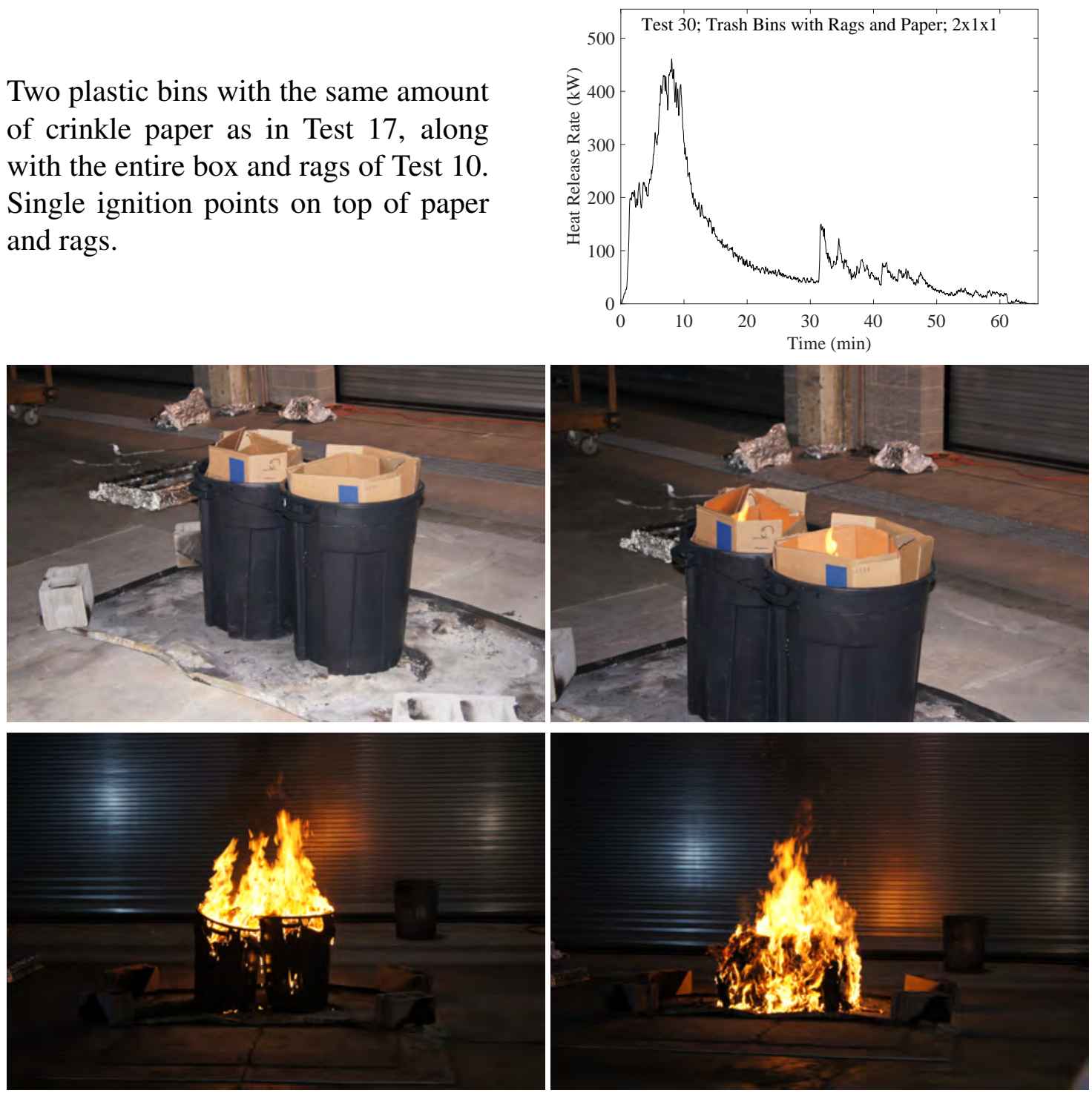

Figure 32: Heat release rate and photographs of Test 30. 


\subsection{Test 31, Four Plastic Bins Filled with Rags and Paper}

Four plastic bins with the same amount of crinkle paper as in Test 17, along with the entire box and rags of Test 10. Single ignition points on top of paper and rags.
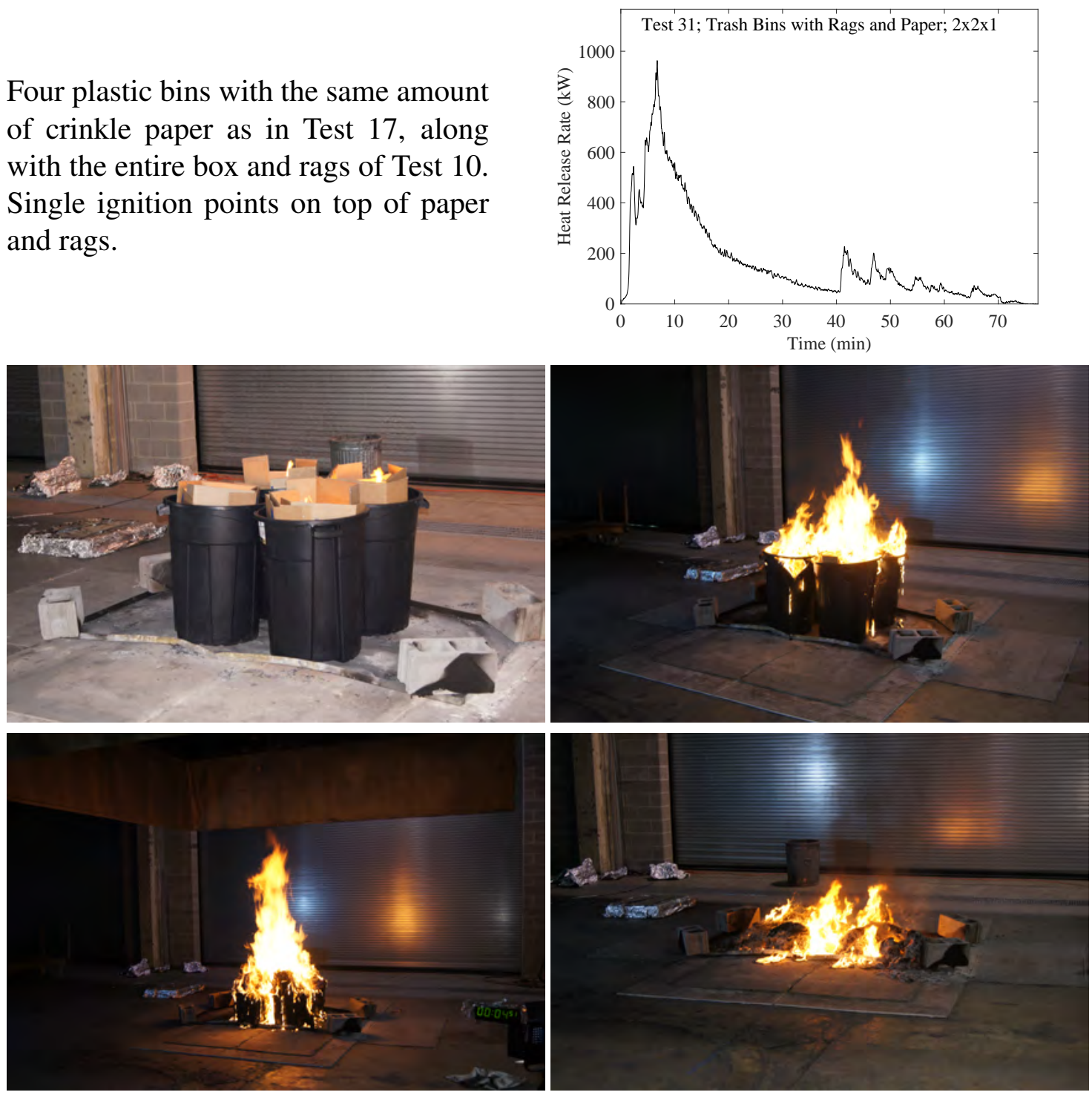

Figure 33: Heat release rate and photographs of Test 31. 


\subsection{Test 32, Single Box with Crinkle Paper, Single Ignition Point}
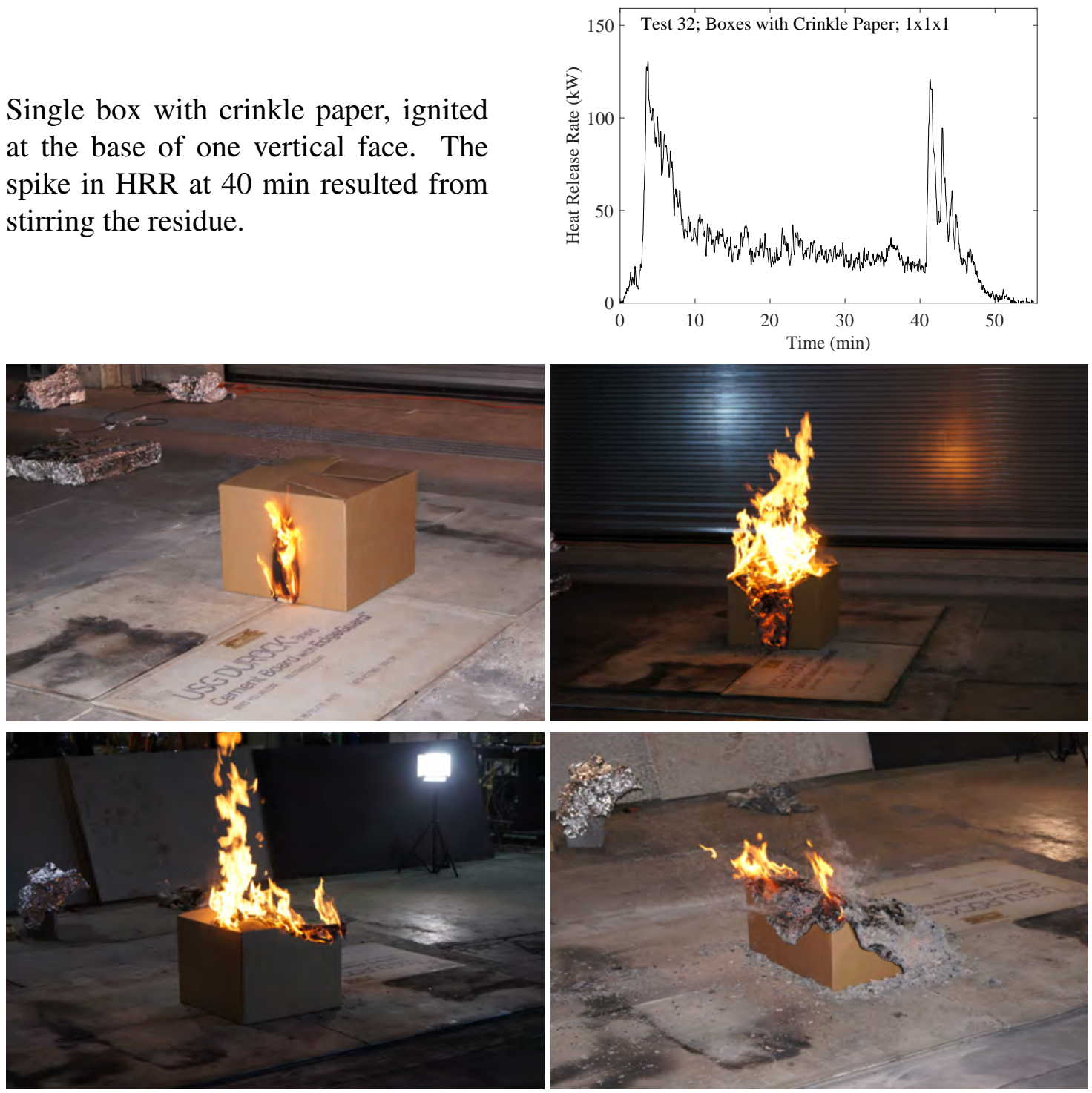

Figure 34: Heat release rate and photographs of Test 32. 


\subsection{Test 33, Two Boxes with Crinkle Paper, Single Ignition Point}
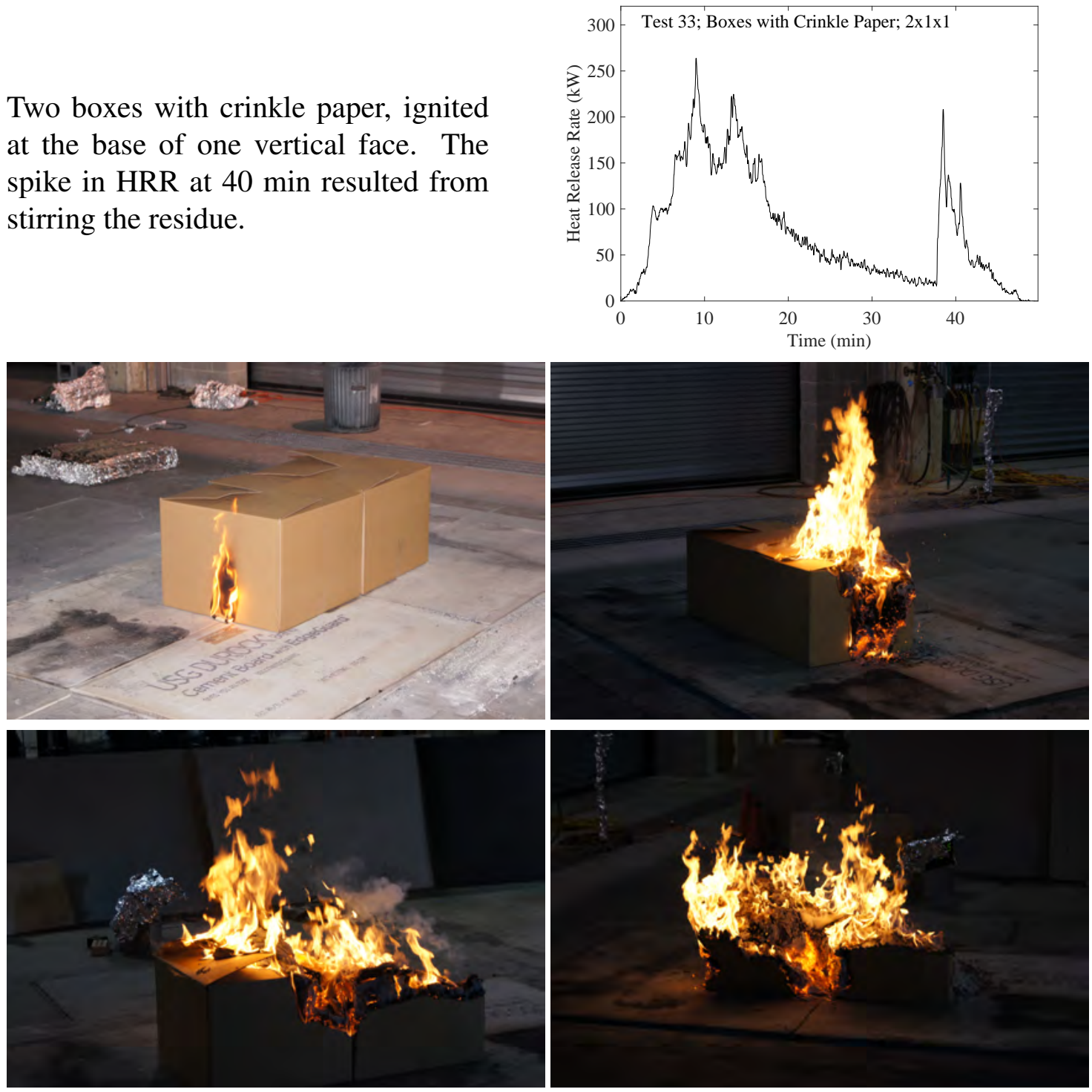

Figure 35: Heat release rate and photographs of Test 33. 


\subsection{Test 34, Four Boxes with Crinkle Paper, Single Ignition Point}
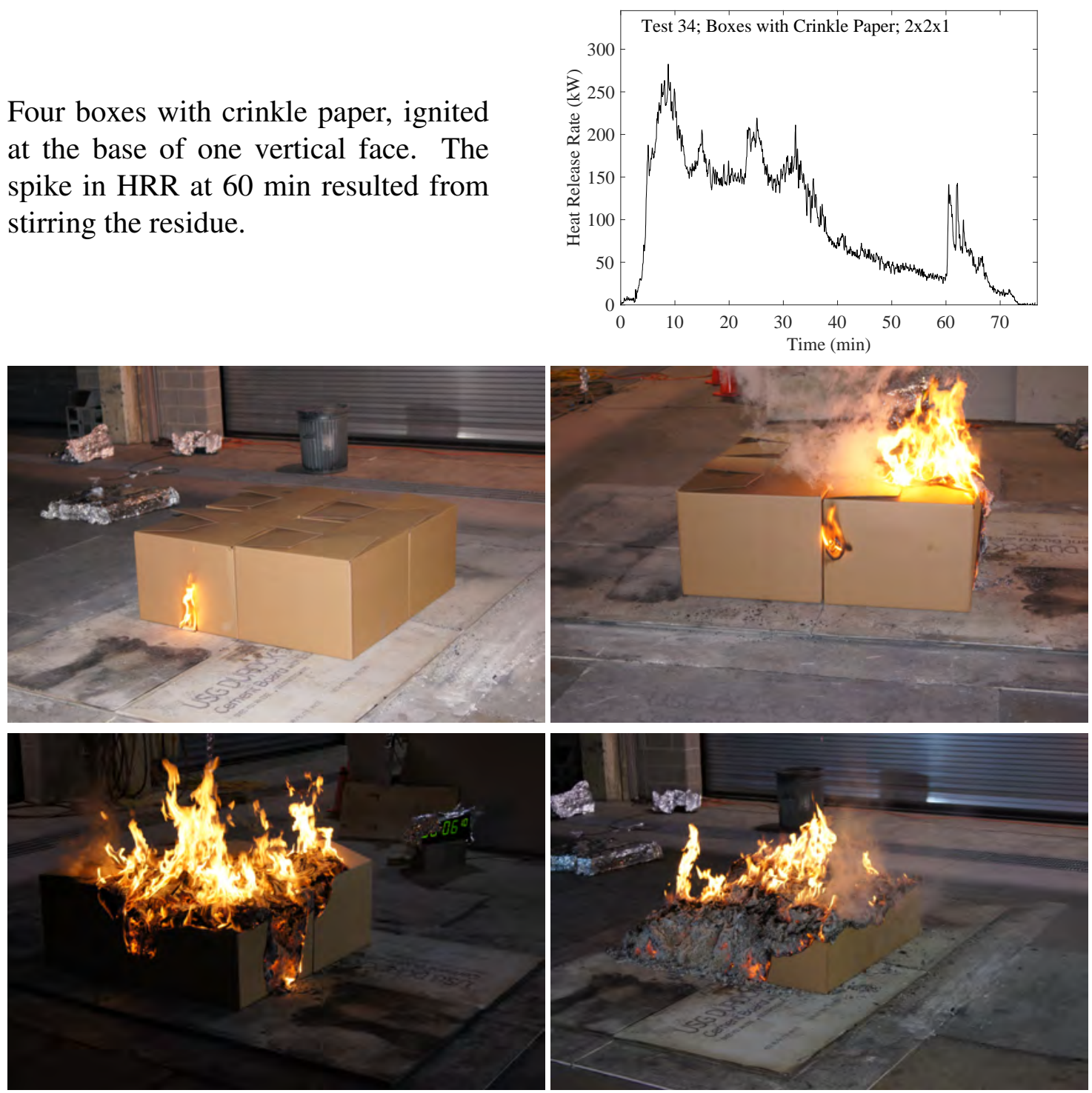

Figure 36: Heat release rate and photographs of Test 34. 


\subsection{Test 35, Eight Boxes of Rags}

Eight boxes filled with cotton rags, ignited at eight points. The spike in HRR at $60 \mathrm{~min}$ resulted from stirring the residue.
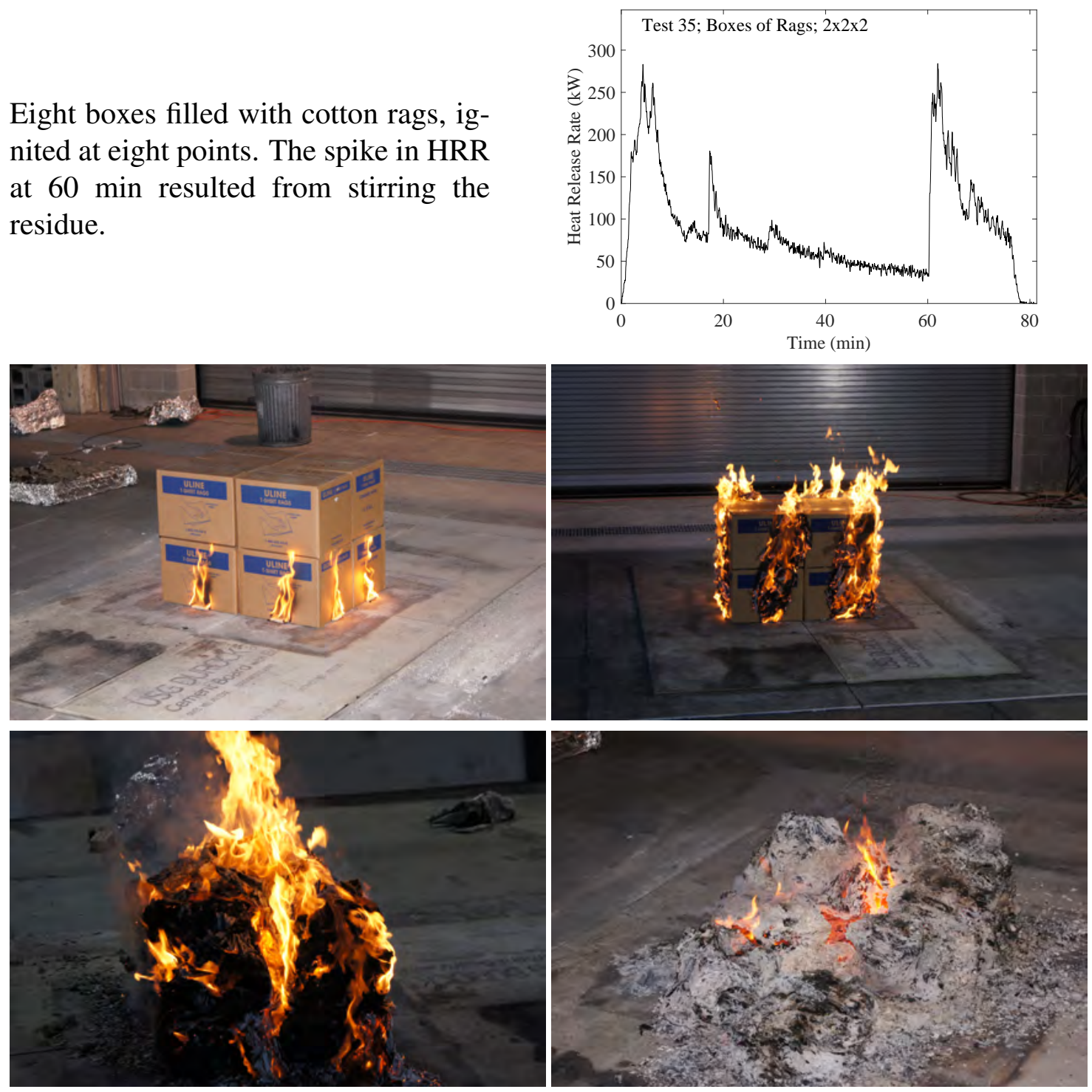

Figure 37: Heat release rate and photographs of Test 35. 


\subsection{Test 36, Two Plastic Trash Bins Filled with Crinkle Paper, One Inside the Other}

Two plastic trash bins stacked together and filled with crinkle paper. Single ignition point on top of paper in the bin. The spike in HRR at 32 min and 46 min resulted from stirring the residue.
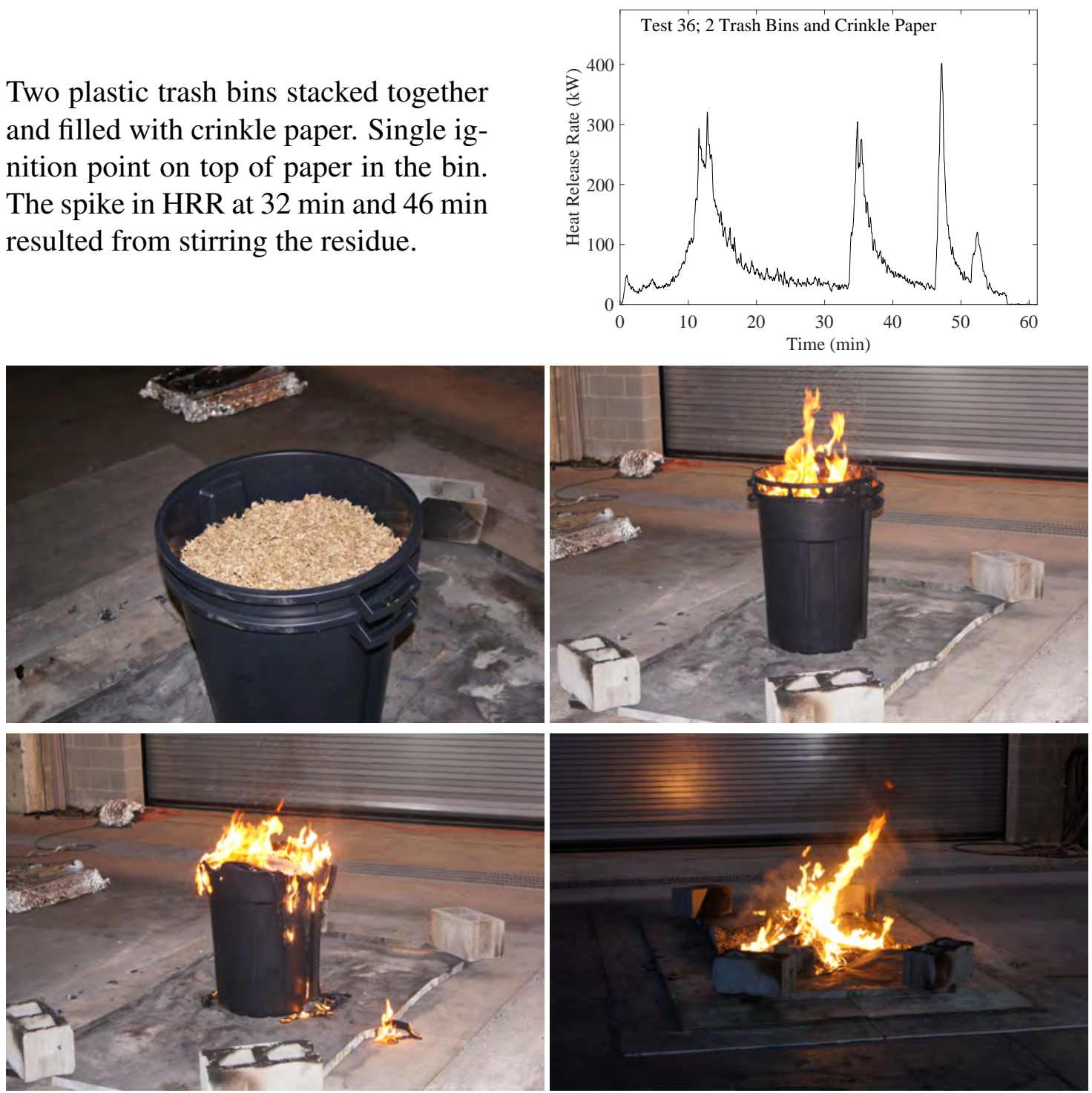

Figure 38: Heat release rate and photographs of Test 36. 


\subsection{Test 37, Four Boxes with Crinkle Paper, Separated}

Four boxes with crinkle paper, ignited at the base of each exterior vertical face (8 ignition points). The boxes are separated by $0.6 \mathrm{~m}(2 \mathrm{ft})$. The residue was stirred up at approximately $20 \mathrm{~min}$ and $28 \mathrm{~min}$.
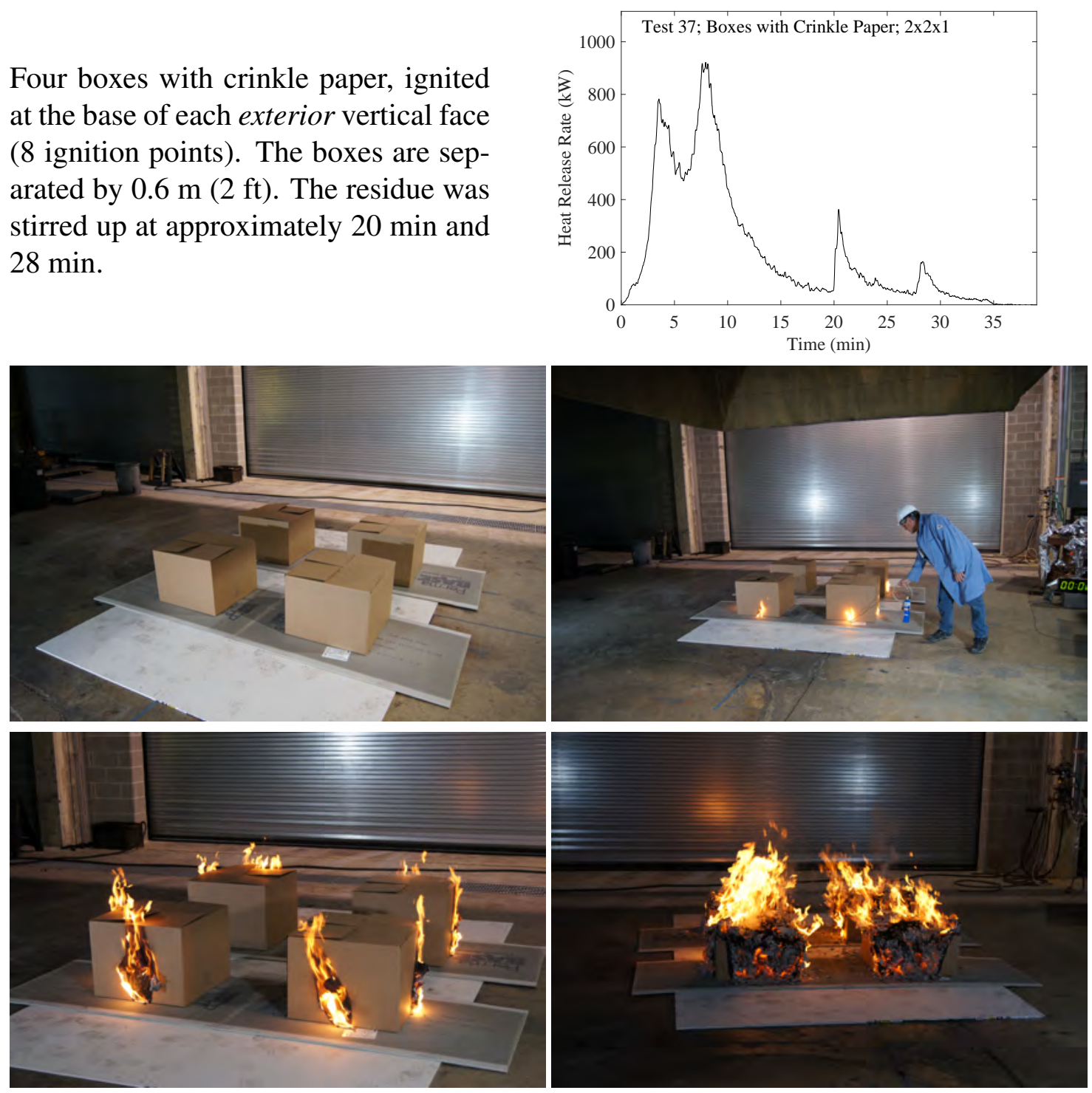

Figure 39: Heat release rate and photographs of Test 37. 


\subsection{Test 38, Four Boxes with Crinkle Paper, Separated}

Four boxes with crinkle paper, ignited at the base of each vertical face (16 ignition points). The boxes were separated by $0.6 \mathrm{~m}(2 \mathrm{ft})$. The residue was stirred up at approximately $23 \mathrm{~min}$.
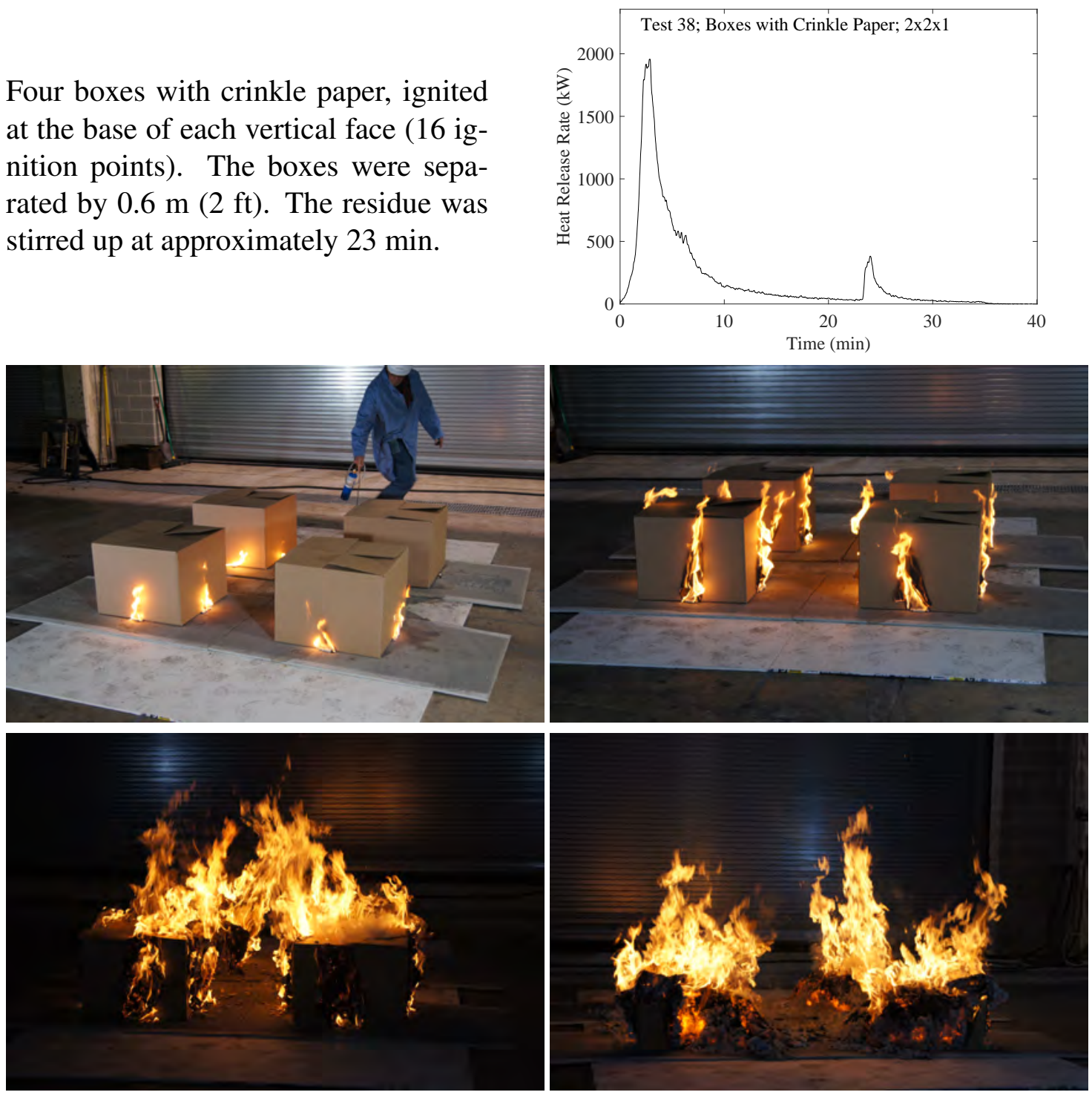

Figure 40: Heat release rate and photographs of Test 38. 


\subsection{Test 39, Four Plastic Trash Bins Filled with Crinkle Paper, Separated}

Four plastic trash bins, half filled with crinkle paper, separated by the top diameter, and set within individual steel pans. Single ignition point on top of paper in each bin. The residue was stirred up at approximately $30 \mathrm{~min}$ and $40 \mathrm{~min}$.
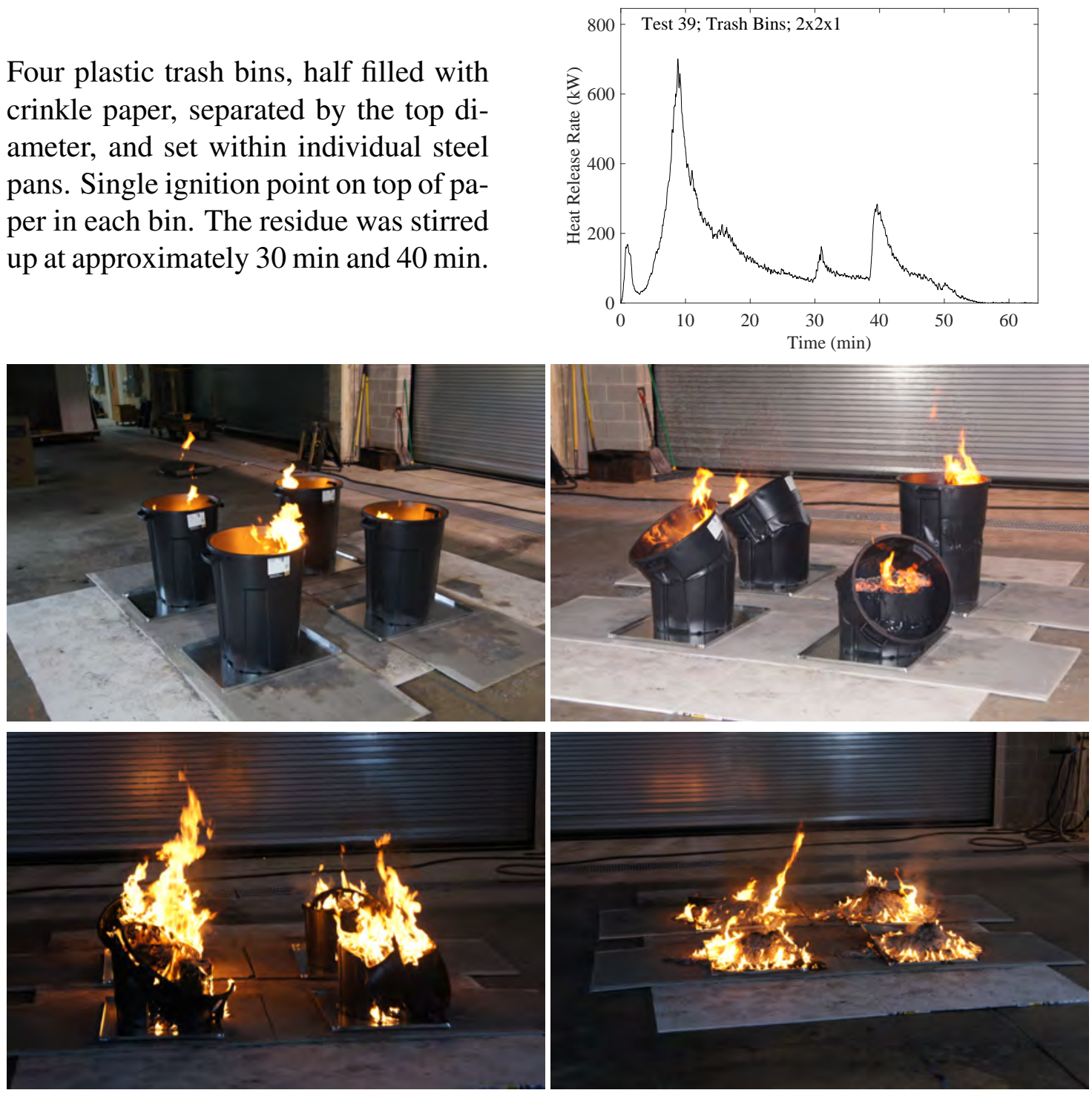

Figure 41: Heat release rate and photographs of Test 39. 


\subsection{Test 40, Four Boxes, Plastic Commodity}

Four boxes filled with polystyrene cups, ignited at the base of each vertical face (16 ignition points). Similar to Test 27, but the boxes were separated by $0.53 \mathrm{~m}$ (21 in).
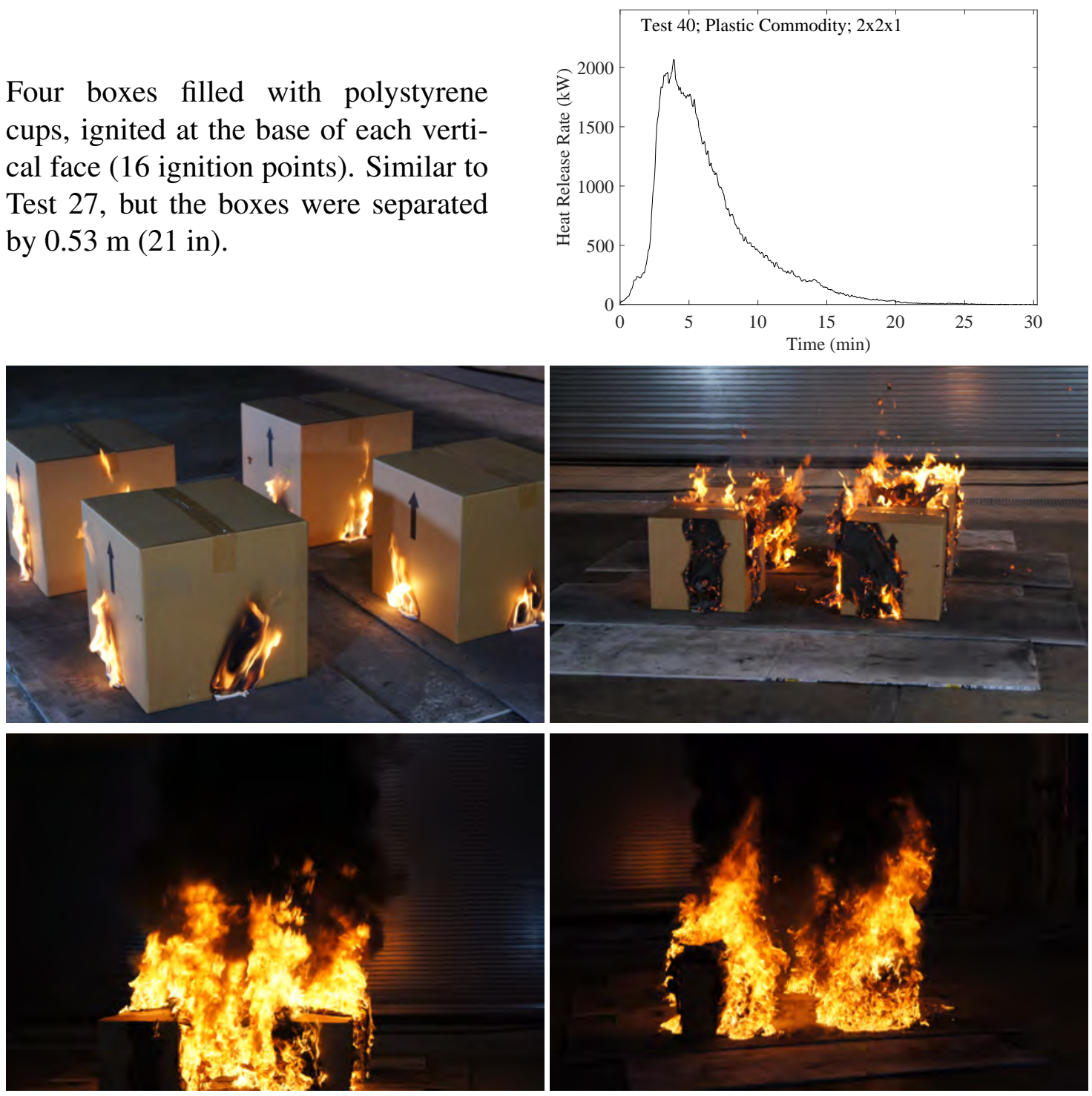

Figure 42: Heat release rate and photographs of Test 40. 


\section{Discussion}

In general, the peak heat release rate (HRR) of the fires occurred at the same time or shortly after all of the exposed surface area of the burning item was engulfed in flame. This suggests that the peak HRR is proportional to the exposed surface area. Figure 43 displays the relationship between the increased peak HRR of multiple items as a function of the relative increase in surface area. In theory, the relationship should be linear, i.e. double the surface area, double the HRR. In the case of the box fires, two boxes sitting side be side have $8 / 5=1.6$ times the exposed surface area of a single box. A 2 by 2 array of four boxes has $12 / 5=2.4$ times the area. A 2 by 2 by 2 array of eight boxes has $20 / 5=4$ times the area. For stacked pallets, four pallets have approximately 1.8 times the surface area of two; eight pallets have approximately 3.4 times the surface area of two. However, for multiple cribs and bins, the exposed surface area is nearly linearly proportional to the number of items. There is a small amount of overlap in the exposed surfaces of the wood cribs, but not much.

Of course, there are exceptions to the simple rule, and in the sections to follow, the various items and test parameters are examined in more detail.

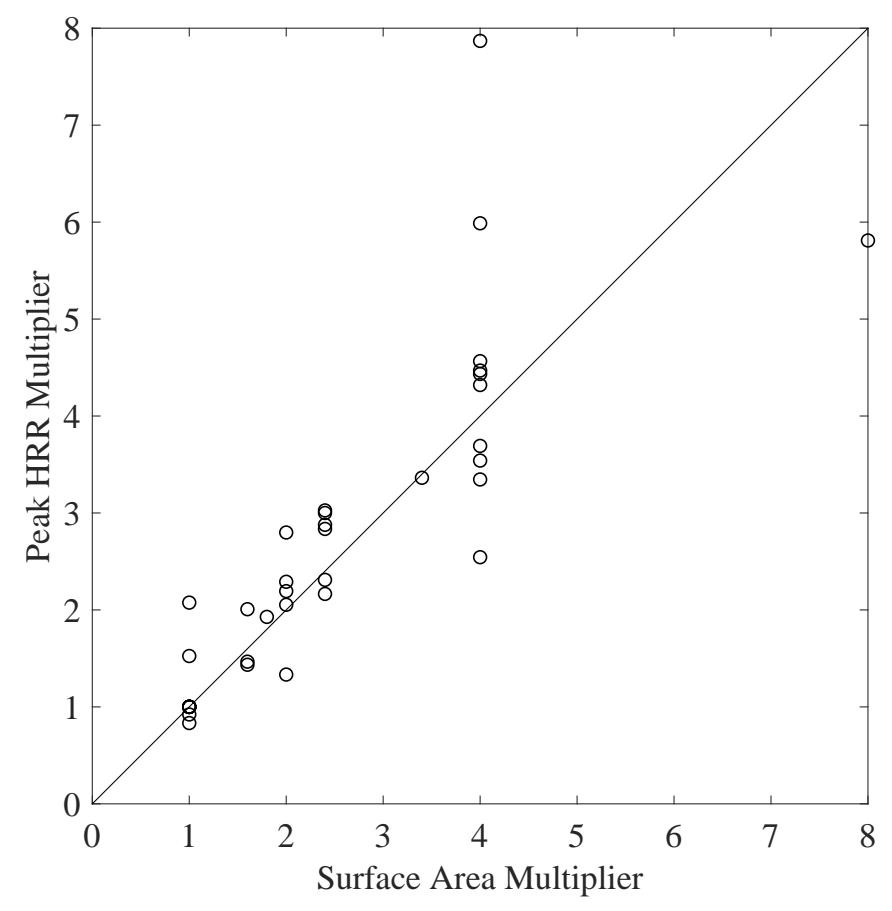

Figure 43: Increase in peak HRR as a function of increasing surface area. 


\subsection{Boxes}

Figure 45 displays the HRR of one, two, four, and eight boxes filled with crinkle paper (top), polystyrene cups (middle), and cotton rags (bottom). The results for the crinkle paper and polystyrene cups are fairly typical for simply-shaped items whose burning rate is largely a function of surface area. The results for the boxes of rags, however, do not exhibit this simple trend, probably because the cotton rags are packed tightly in the boxes and do not burn readily. When the pile of residue was first stirred up, a considerable amount of the combustible mass remained buried under the pile of ash.

One complication of the simple assumption that peak HRR is proportional to exposed surface area is that in many instances, the fire does not or cannot engulf all of the exposed surface area at the same time. The location and power of the ignition source(s) is important. Consider the boxes of crinkle paper burned in Tests 32-34 (Fig. 44) versus Tests 1-3 (Fig. 45, top). In the former, only one igniter was used, whereas in the latter, an igniter was placed at the base of each exposed vertical surface. The peak HRR in Tests 1, 2, and 3 is 2.5, 1.8, and 3.3 times that of Tests 32, 33, and 34. Tests 32-34 do not exhibit the linear relationship between peak HRR and exposed surface area.

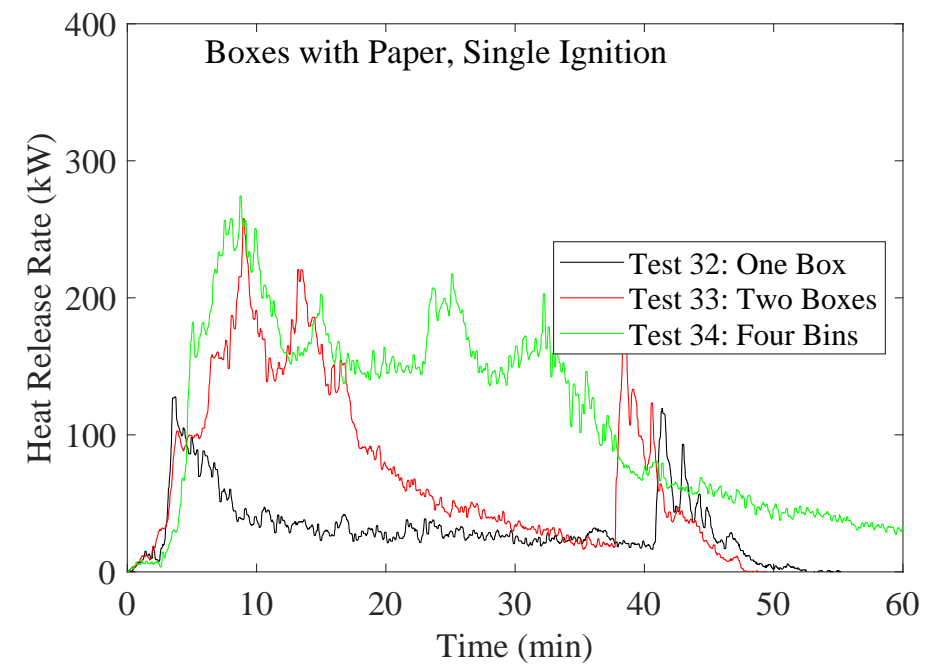

Figure 44: HRR of boxes filled with paper and ignited at a single point. 

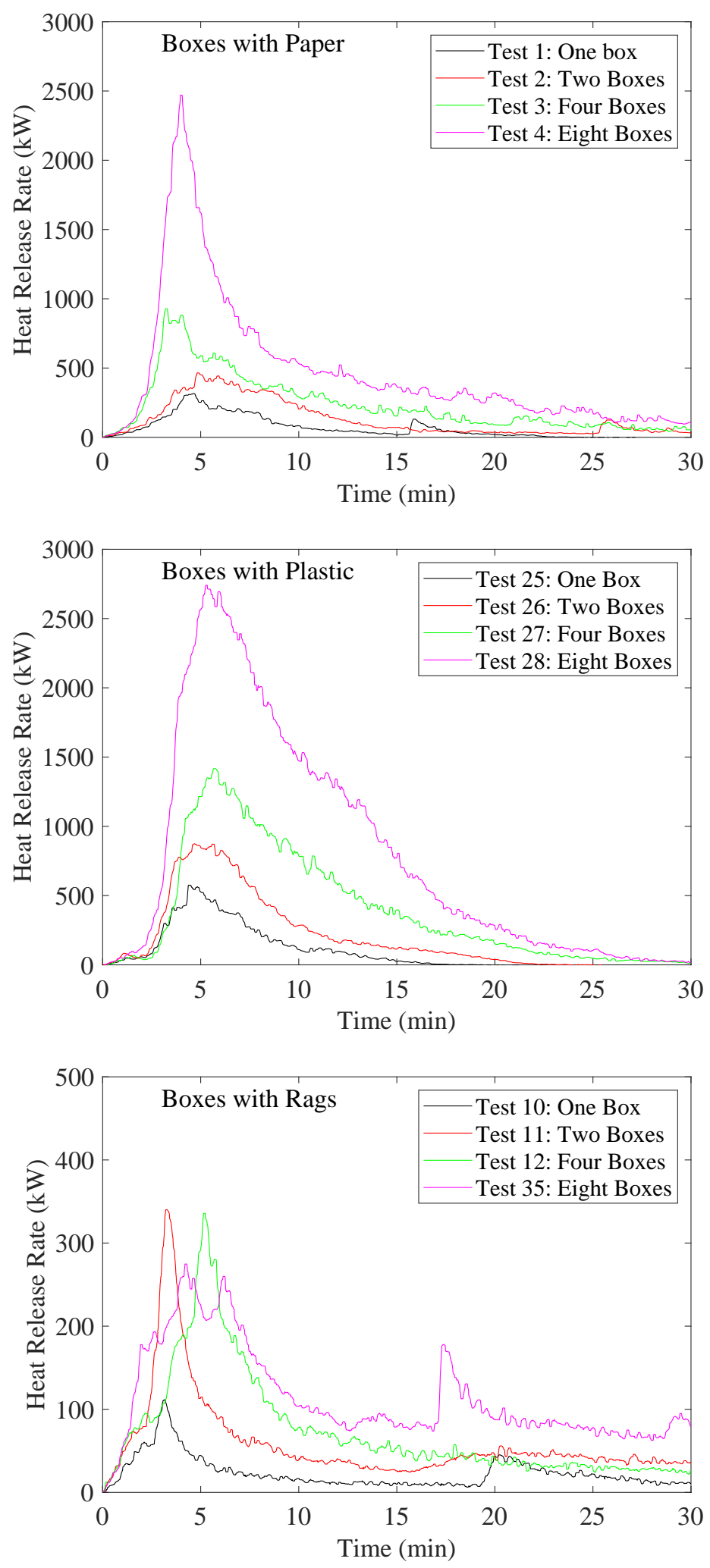

Figure 45: Heat Release Rate of boxes filled with crinkle paper (top), polystyrene cups (middle), and cotton rags (bottom). 


\subsection{Wood Pallets and Cribs}

Wood pallets and cribs are often used in fire testing because they exhibit reliable and repeatable burning behavior. This can be seen in the results shown in Fig. 46. The top plot shows the HRR for single stacks of pallets consisting of two, four, and eight pallets (a single pallet is difficult to burn without a heat source to sustain the fire). The peak HRR is nearly linear with the number of pallets because the surface area is nearly linear with the number of pallets. This trend is noted by Babrauskas in the SFPE Handbook [5]. 

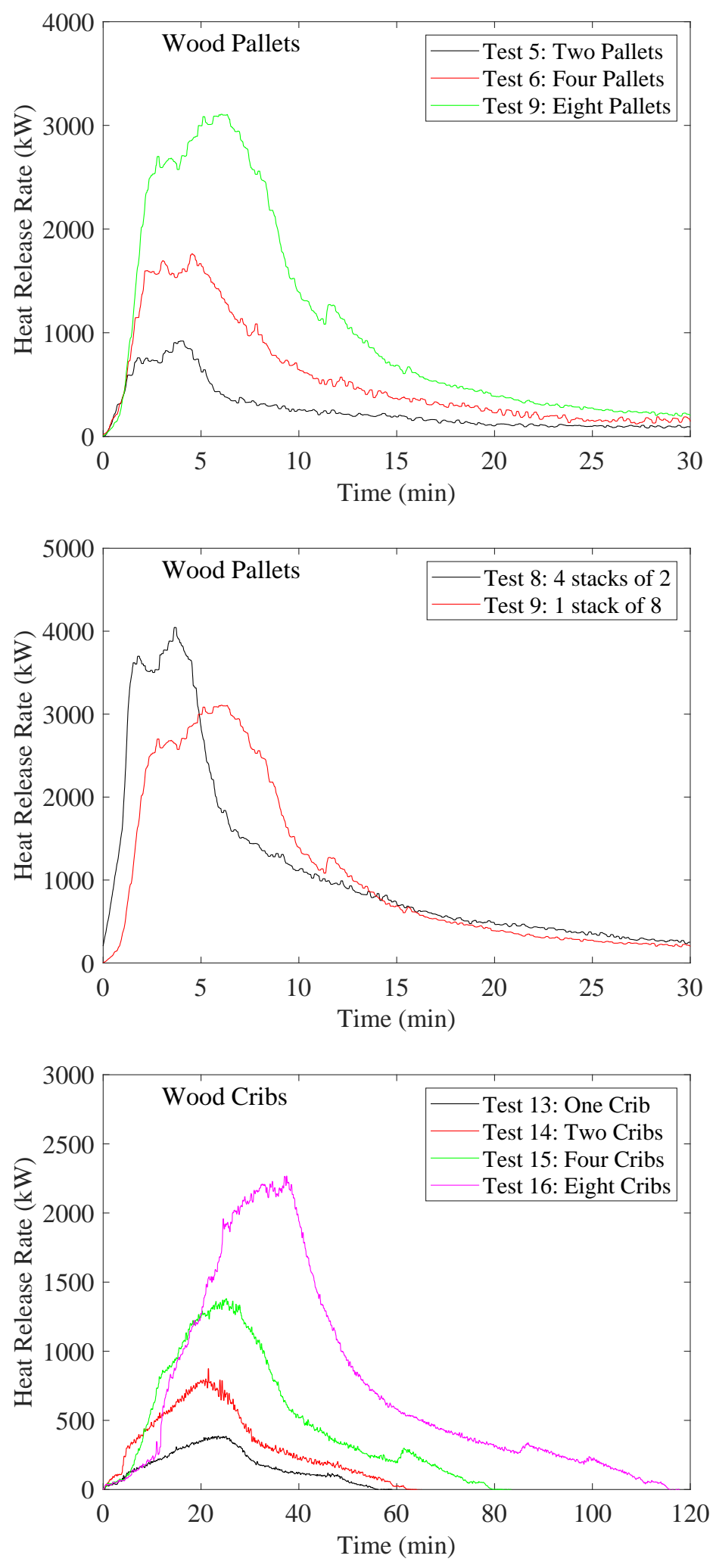

Figure 46: Heat Release Rate of pallets and cribs. 


\subsection{Plastic Trash Bins}

The plastic trash bins were either partially filled with crinkle paper or completely filled with crinkle paper, cardboard, and rags. In the latter case (bottom graph of Fig. 47), the cellulosic fuels dominate the burning behavior and the simple trend in peak HRR emerges. In the former case, the trend for the peak HRR is less clear because the burning behavior is dominated by the melting, dripping, and pooling of plastic, something that is less repeatable in multiple experiments.
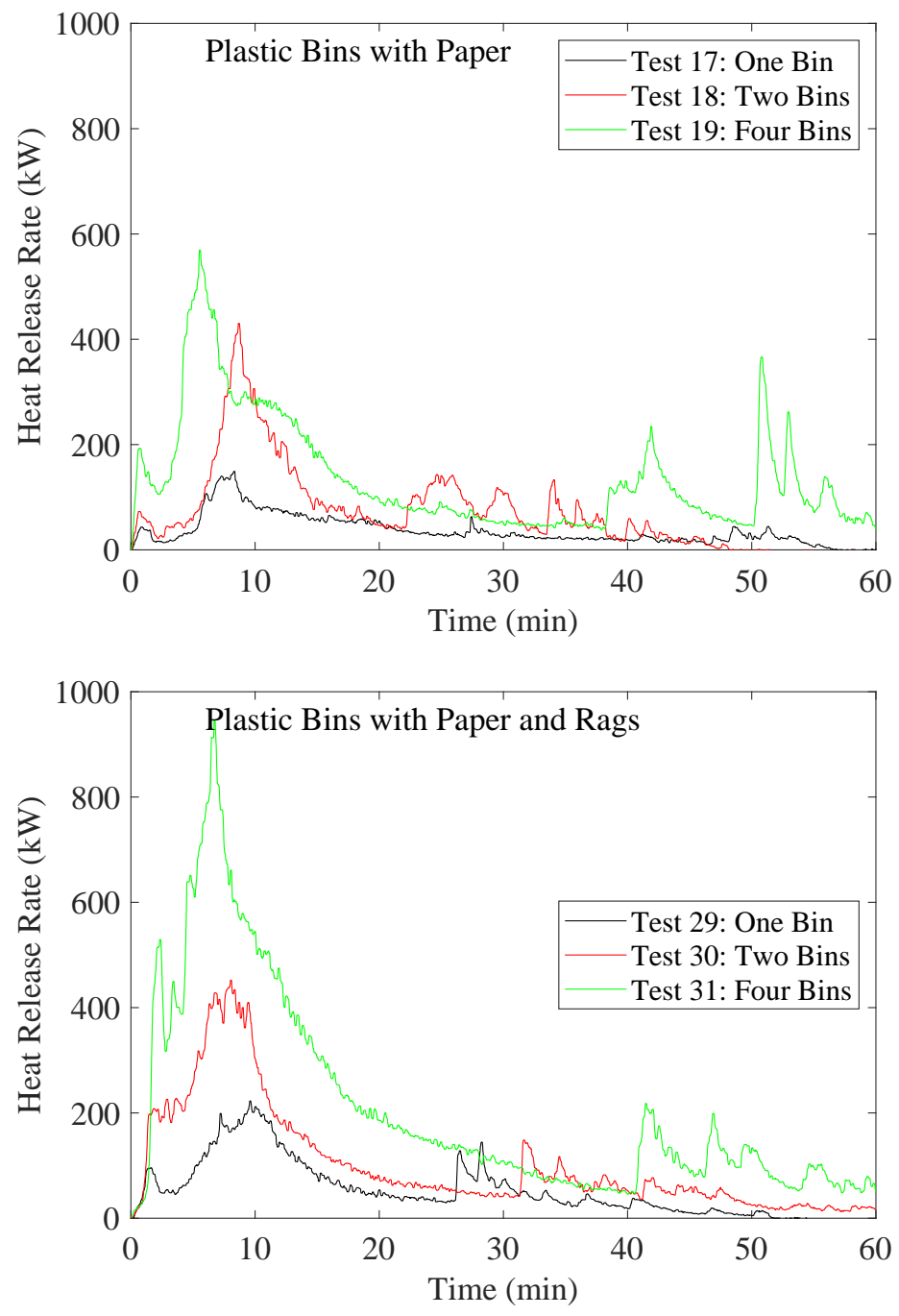

Figure 47: Heat Release Rate of plastic trash bins. 


\subsection{Combinations}

There are a few examples where multiple items have been burned together and separately. For example, Test 20 is a combination of the items included in Tests 5 and 19, where four plastic bins filled with crinkle paper (Test 19) stand atop two pallets (Test 5). The resulting peak HRR of the combined items is $50 \%$ greater than the sum of the individual peak HRRs. However, Test 21 is a combination of Tests 4 and 5 (eight boxes sitting atop two pallets), but the peak HRR of the combined items is only $92 \%$ of the sum of the individual peak HRRs. In the first instance, it appears that the increased radiative feedback from the larger fire enhances the rate of burning of the combined itesm, yet this does not appear to the be the case in the second instance. For Test 36, two plastic bins are nested one inside the other, and the peak HRR doubles, even though the surface area changes very little. There does not appear to be a simple explanation of these cases, which is why the trend shown in Fig. 43 is fairly rough. 


\subsection{Separations}

Most of the 40 experiments conducted involved multiple items placed closely together or stacked. However, in some experiments, the items were separated. By separating the items, the surface area is increased which ought to increase the peak HRR. However, this was not always the case. For example, Fig. 48 displays the HRR of four boxes filled with crinkle paper that were configured and ignited in different ways. In Test 3 , the four boxes were placed side by side and ignited in 8 locations. In Test 35 , the four boxes were ignited only in one location. In Tests 37 and 38, the four boxes were separated by $0.6 \mathrm{~m} \mathrm{(2ft)}$ and ignited with 8 and 16 igniters, respectively. There is a significant difference in the peak HRR in these cases, owing as much to the number of igniters as to the nominal exposed surface area. Notice in Tests 3 and 37, the number of igniters is the same, and the initial peak in the HRR involves roughly the same amount of surface area; however in Test 37, where the boxes were separated, there is a second peak in the HRR owing to the additional exposed surface area.

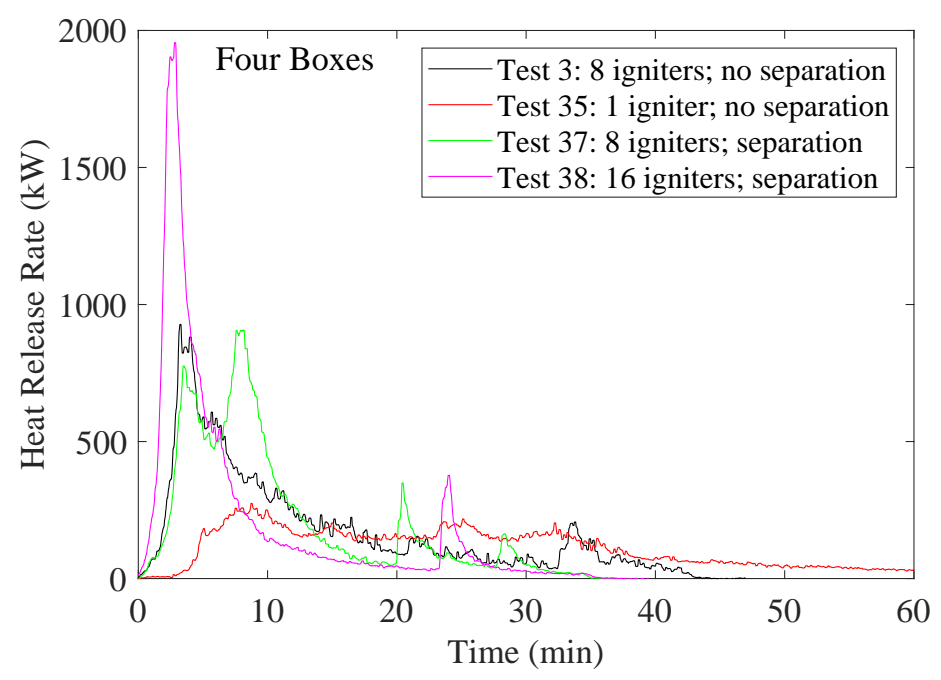

Figure 48: Heat Release Rate of four boxes filled with crinkle paper. 


\section{Conclusion}

Forty experiments were conducted in which multiple quantities of transient combustibles were burned and their heat release rates (HRR) measured, with the objective to determine the HRR of multiple items based on the HRR of a single item. The peak HRR is roughly proportional to the exposed surface area, but the configuration of items and the number of ignition points also play a role. Given the infinite number of potential combustibles, configurations, and ignition scenarios, it is not possible to develop a simple rule that would predict the increase in HRR given an increase in the number of combustibles. However, the assumption that the peak HRR is proportional to the exposed surface area will probably suffice for most practical applications.

\section{Acknowledgments}

This work was partially funded by the U.S. Nuclear Regulatory Commission, Office of Nuclear Regulatory Research. Matthew Bundy, Michael Selepak, Marco Fernandez and Laurean DeLauter of the National Fire Research Laboratory assisted in conducting these experiments and in processing the data.

\section{References}

[1] A. Lindeman, M. Randelovic, and M. Salley. Heat Release Rate and Fire Characteristics of Fuels Representative of Typical Transient Fire Events in Nuclear Power Plants. NUREG-2232, Nuclear Regulatory Commission, Washington, D.C., August 2019. This work is also published by the Electric Power Research Institute as EPRI 3002015997.

[2] M. Salley, A. Lindeman, and M. Randelovic. Methodology for Modeling Transient Fires in Nuclear Power Plant Fire Probabilistic Risk Assessment. NUREG-2233, Nuclear Regulatory Commission, Washington, D.C., December 2019. This work is also published by the Electric Power Research Institute as EPRI 3002016054.

[3] R.A. Bryant and M.F. Bundy. The NIST 20 MW Calorimetry Measurement System for Large-Fire Research. NIST Technical Note 2077, National Institute of Standards and Technology, Gaithersburg, Maryland, December 2019.

[4] M.J. Hurley, editor. SFPE Handbook of Fire Protection Engineering. Springer, New York, 5th edition, 2016.

[5] V. Babrauskas. SFPE Handbook of Fire Protection Engineering, chapter Heat Release Rates. Springer, New York, 5th edition, 2016. 